University for Business and Technology in Kosovo

UBT Knowledge Center

Fall 10-2019

\title{
Studimi i UMGJ-ve në Republikën e Kosovës veçanërisht tek misri i importuar dhe vendor
}

Diellëz Arifi

University for Business and Technology - UBT

Follow this and additional works at: https://knowledgecenter.ubt-uni.net/etd

Part of the Food Science Commons

\section{Recommended Citation}

Arifi, Diellëz, "Studimi i UMGJ-ve në Republikën e Kosovës veçanërisht tek misri i importuar dhe vendor" (2019). Theses and Dissertations. 11.

https://knowledgecenter.ubt-uni.net/etd/11

This Thesis is brought to you for free and open access by the Student Work at UBT Knowledge Center. It has been accepted for inclusion in Theses and Dissertations by an authorized administrator of UBT Knowledge Center. For more information, please contact knowledge.center@ubt-uni.net. 


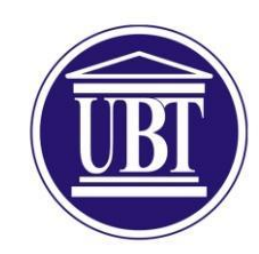

Kolegji UBT

Fakulteti i Shkencave të Ushqimit me Bioteknologji

STUDIMI I OMGJ-VE NË REPUBLIKËN E KOSOVËS VEÇANËRISHT TEK MISRI I IMPORTUAR DHE VENDOR

Shkalla Bachelor

Diellëz Arifi

Tetor, 2019, Prishtinë 


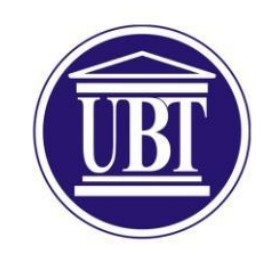

Kolegji UBT

Fakulteti i Shkencave të Ushqimit me Bioteknologji

Punim Diplome

Viti akademik 2016-2017

Diellëz Arifi

\title{
STUDIMI I UMGJ-VE NË REPUBLIKËN E KOSOVËS VEÇANËRISHT TEK MISRI I IMPORTUAR DHE VENDOR
}

\author{
Mentori: Ismail Ferati
}

Tetor, 2019

(C2019-Diellëz Arifi

Të gjitha të drejtat e rezervuara

Ky punim është përpiluar dhe dorëzuar në përmbushjen e kërkesave të pjesshme për Shkallën Bachelor 


\begin{abstract}
ABSTRAKT
Organizmat e modifikuar gjenetikisht janë ushqime të prodhuara nga organizmat që kanë pësuar ndryshime në ADN-në e tyre duke përdorur metodat e inxhinierisë gjenetike dhe biologjisë molekulare. Kulturat apo kultivarët e modifikuar gjenetikisht janë projektuar për rezistencë ndaj patogjenëve dhe herbicideve, për të shtuar veti më të mira ushqyese, për të fituar më shumë ekonomikisht dhe për të humbur më pak etj. Në këtë studim janë analizuar disa mostra nga prodhues të ndryshëm (vendor dhe të jashtëm), kultivarët e të cilëve përbëjnë një përqindje të madhe në të ushqyerit bazë në RKS, sidomos në vendet rurale dhe veçanërisht kjo lëndë e parë me origjinë bimore, misri, përbën ushqimin kryesor nëpër ferma brenda RKS. Mostrat janë marrë në baza të rëndomta konceptualisht nga produkti i misrit dhe nga vet misri. Kjo temë dhe ky problem në Kosovë është relativisht i ri andaj është parë e nevojshme që në këtë studim të ngrihen shqetësime përmes analizave dhe teorive shkencore, duke sqaruar se çka janë OMGJ-të, pse prodhohen ato, efektet anësore të tyre (shëndeti, mjedisi) dhe dallimet që duhet bërë, ndarja nga faktet dhe mitet, prodhimi vendor vs i importuar, gjykimi objektiv i cili në rend të parë ka ekonominë që funksionon për shoqërinë dhe jo shoqërinë e cila funksionon për ekonominë dhe më e rëndësishmja sundimi i ligjit dhe si e trajton ligji i ushqimit në RKS temën në fjalë.
\end{abstract}




\section{MIRËNJOHJE/FALENDERIM}

Ushqimi është artikulim i Diellit. Dielli është jetë. Të studiosh ushqimin është jetë. Ky hulumtim nuk do të ishte i mundur pa njerëzit që mendojnë se ushqimi dhe përkushtimi ndaj tij na kthen në fillet tona, në tokë. Prodhimi vendor është mendimi dhe puna e një populli, prandaj edhe ekonomia e tij. Atdheu është vendi i duhur ku mendimi dhe puna të mbështetura nga qeveria, marrin vlerën e zhvillimit. Mbështetja për prodhimet vendore duhet të jetë detyrë e secilit prej nesh, në mënyrë që të bëhet shpëtimi ynë. Pa profesorë që mendojnë ngjashëm, vullneti për hulumtime të tilla nuk do të ishte i njëjti. Realizmi i kësaj teme, ndoshta edhe vetëm trajtimi i saj, padyshim që ka qenë sfiduese, që nga ideja e temës e deri te metodat e trajtimit të saj. Prandaj, pafundësisht faleminderit mentorit që së pari ka besuar se unë mund ta trajtoj këtë temë dhe pastaj për mbështetjen e vazhdueshme dhe kritikën konstruktive në çdo hap të studimeve. Faleminderit familjes, shoqeve e shokëve që ma kanë kujtuar çdo ditë se sa shumë më besojnë dhe sa shumë ka rëndësi për ta dhe shoqërinë në përgjithësi fakti që studioj këtë fushë dhe guximi për të trajtuar këtë temë. Në fund faleminderit edhe vetes që kam kalkuluar gjithmonë studimin si diçka më të madhe se veten, andaj se kam humbur vullnetin për asnjërën ende. 


\section{P ËRM B A J T J A :}

1. HYRJE 8

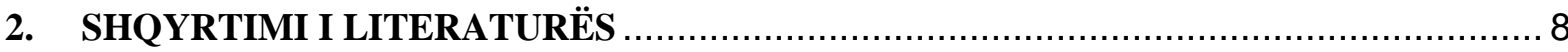

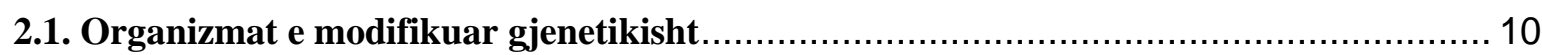

2.1.1. Bimët e modifikuara gjenetikisht ............................................................. 10

2.1.2. Ushqimet e modifikuara gjenetike .............................................................. 11

2.2. Hyrje në treg e ushqimeve të modifikuara gjenetike ............................................. 12

2.3. Llojet e ushqimeve të modifikuara gjenetikisht.................................................... 15

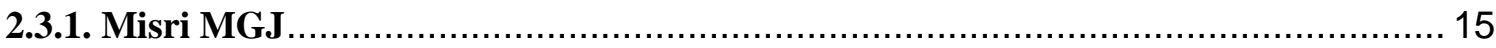

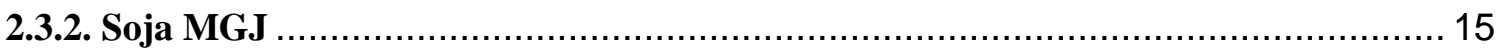

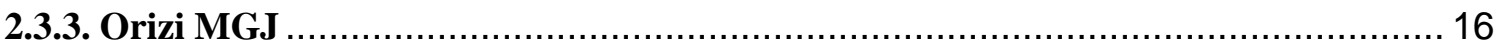

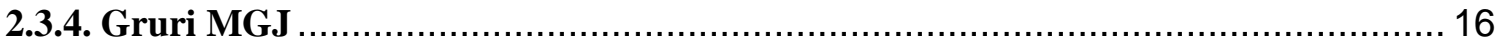

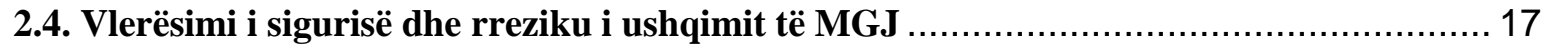

2.4. Ndikimi i bimëve të MGJ në kualitetin e ushqimit me origjinë shtazore ….................. 18

2.5. Përparësitë e mundshme dhe disavantazhet e modifikimit gjenetik për bujqësinë ......... 19

2.5.1. Degradimi i shpejtë i $\boldsymbol{\beta}$-karotenit tek orizi i artë .............................................. 21

2.5.2. Ndikimi i OMGJ-ve për biodiversitetin dhe ekosistemin ................................. 21

2.5.3. Ndikimi i konsumit të UMGJ për shëndetin e njeriut ….................................. 23

2.5.4. Efektet potenciale pozitive të UMGj në shëndetin e njeriut ................................ 23

2.5.4.1. Biofortifikimi i mineraleve në UMGJ ........................................................ 24

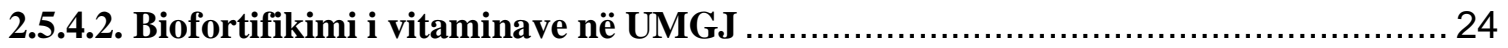

2.5.5. Efektet potenciale negative të UMGJ mbi shëndetin e njerëzve ............................26

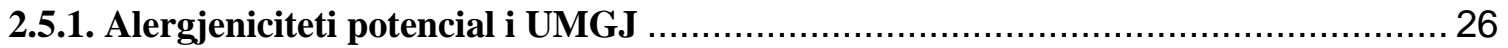

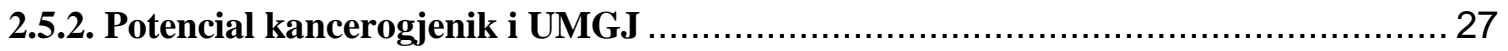

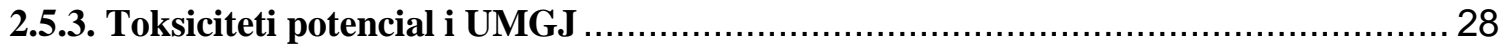

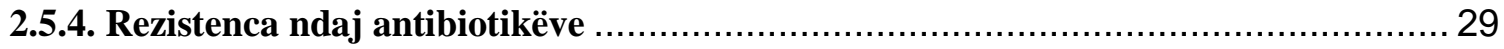

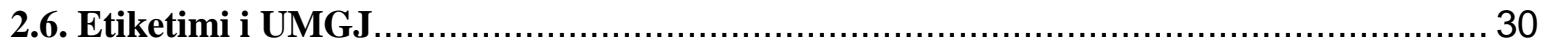

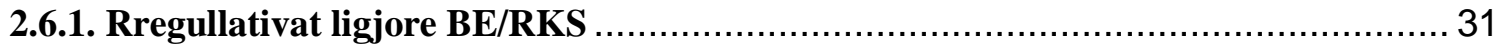

4. PREZANTIMI DHE ANALIZA E REZULTATEVE............................................... 35

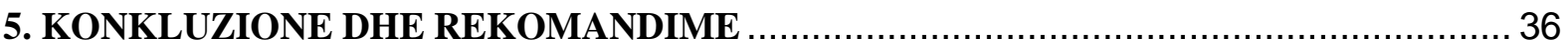

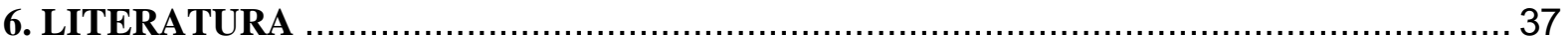




\section{LISTA E FIGURAVE}

Figura 1. Numri i vendeve që kanë lëshuar miratimin për kulturat e modifikuara gjenetikisht

Figura 2. Numri i ngjarjeve transgjenike në 26 kulturat e miratuara për të ushqyerit ${ }^{16}$

Figura 3. Numri i ngjarjeve transgjenike të miratuara në periudhën 1992 deri $2017^{20}$ 14

Figura 4. Kultivimi i bimëve si pika fillestare e zinxhirit ushqimor..................................... 18

Figura 5. Përqindja e karotenoidit të mbajtur në frytet e varieteteve të egra dhe transgenike të bananeve. ${ }^{69}$

\section{LISTA E FOTOVE}

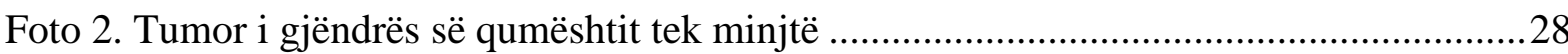

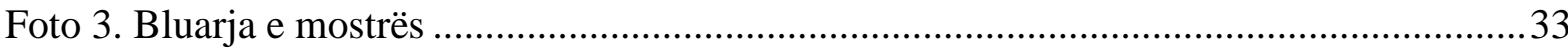

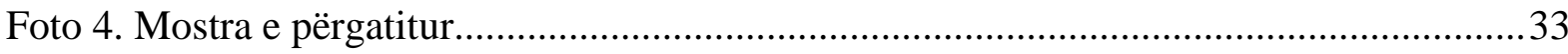

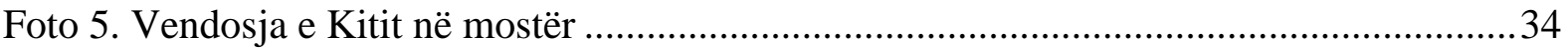

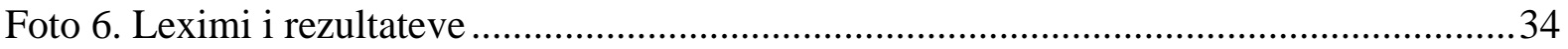

\section{LISTA E TABELAVE}

Tabela 1. Pasqyrë e katër gjeneratave të kulturave gjenetikisht të modifikuara18 .................. 12

Tabela 2. Përmbledhje e studimeve eksperimentale të toksicitetit të ushqimeve OMGJ ndaj

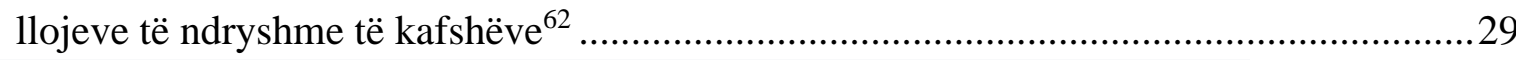

Tabela 3. Rezultatet e testimit të mostrave të misrit vendor dhe atij të importit .....................35 


\section{FJALORI I TERMAVE}

OMGJ - organizmat e modifikuara gjenetikisht

UMGJ - Ushqimet e modifikuara gjenetikisht

MGJ - Modifikim gjenetik ADN- Acidi dezoksiribonukleik

OBSH - Organizata botërore e shëndetësisë (WHO)

FAO - Food and Agriculture Organization

FDA - Food and Drug Administration

CBD - Konventën për Diversitetin Biologjik

MGJHTs- Genetically modified herbicide tolerant

Gjenoma - është materiali gjenetik i kompozuar nga kromozome të vendosur në bërthamën e çdo qelize.

Organizmat transgjenike - Prodhimi i organizmave transgjenik përfshinë ndryshimin e gjenomit, kështu që realizohet një ndryshim i përhershëm. 


\section{HYRJE}

Pjesë e teknologjisë gjenetike që kombinon material trashëgues (gjen) nga organizma të ndryshëm (bimë, kafshë dhe mikroorganizëm) quhet teknologji e rekombinantës së ADN-së ose inxhinieri gjenetike. Organizmi që lind si rezultat i një kombinimi të gjeneve është një organizëm i modifikuar gjenetikisht (OMGJ). Ushqimi që përmban ose rrjedh nga një organizëm i modifikuar gjenetikisht përbën ushqim të modifikuar gjenetikisht (UMGJ) ${ }^{1}$.

Duke përdorur teknologjinë e rekombinimit të ADN-së, krijohet një organizëm me veti të caktuara të dëshiruara dhe në fushën e prodhimit të ushqimit me qëllim arritjen e rezistencës ndaj insekteve dhe viruseve, tolerancën ndaj herbicideve dhe vlerën ushqyese të përmirësuar të ushqimit. Sot ekzistojnë disa teknika me anë të cilave një ADN e veçantë futet në qelizat e synuara, me ADN që lidhet kryesisht me bartësin e gjeneve, roli i të cilit është konfirmimi i transmetimit të ADN-së. ${ }^{2}$

Metodat e inxhinierisë gjenetike manipulojnë gjenomin e të gjitha llojeve të organizmave. Për prodhimin e ushqimit, i cili do të përdoret në dietën e popullsisë së botës, më të rëndësishmit janë bimët. Ata përfaqësojnë burimin kryesor të ushqimit në botë dhe janë në thelb piramidat e një diete të duhur. Modifikimi gjenetik i bimëve ka mundësuar prodhimin e kulturave bimore me përbërje të përmirësuar ushqyese dhe rezistencë më të madhe ndaj kushteve të pafavorshme mjedisore, duke arritur rendiment të lartë në sipërfaqe të vogla. Në kontekst të plotësimit të nevojave ushqimore botërore, ushqime me origjinë shtazore janë gjithashtu të rëndësishme. Në këtë rast, indirekt, ndikimi i tyre shprehet me bimë, të cilat përdoren gjithashtu si ushqim për kafshët. Modifikimi gjenetik i kafshëve gjen zbatim më të madh në mjekësi, për prodhimin dhe testimin e barnave të reja. Kur është fjala për mikroorganizmat gjenetikisht të modifikuara, rëndësia e tyre është në përmirësimin e karakteristikave të ushqimeve bazë siç janë pamja, ngjyra, aroma dhe cilësi. ${ }^{3}$ Kulturat e modifikuara gjenetikisht, të cilat janë prodhuar kryesisht për rezistencë ndaj herbicideve dhe insekticideve, siç janë misrit, pambukut, sojës dhe rrepa vajore. Përveç këtyre, sot në treg ka edhe patate të ëmbla, oriz dhe banane të modifikuara gjenetikisht me përmbajtje të shtuar të vitaminës A, etj. ${ }^{1}$

\section{SHQYRTIMI I LITERATURËS}


Prodhimi i ushqimeve të modifikuara gjenetikisht ka mundësuar rritjen e prodhimit duke reduktuar herbicidet, edhe pse ekziston rreziku i rritjes së barërave të këqija rezistente ndaj herbicideve. ${ }^{4}$ Që nga futja e ushqimit të modifikuar gjenetikisht në treg, shumica e të lashtave të modifikuara gjenetikisht ishin kultura gjenetikisht të modifikuara tolerante ndaj herbicideve (MGJHTs), gjë që nënkuptonte përdorimin e herbicideve glyphosate, e cila reduktoi përdorimin e herbicideve në prodhimin primar të bimëve. ${ }^{5}$

Vitet e fundit janë shënuar ndryshime të rëndësishme klimatike, të cilat mund të ndikojnë në ekosistemin dhe të zvogëlojnë produktivitetin e bimëve të kultivuara. Rënia e rendimentit bujqësor shkakton një sasi të pamjaftueshme të ushqimit me origjinë bimore për të ushqyer popullatën. Kjo vlen veçanërisht për drithërat që janë vendimtarë për konsum njerëzor në vendet me popullsi në rritje. Gjithashtu, rendimenti i reduktuar i bujqësisë ka një ndikim të drejtpërdrejtë në disponueshmërinë e ushqimit për kafshët, dhe rrjedhimisht sasinë e reduktuar të ushqimit me origjinë shtazore.

Një problem i veçantë është mosbalancimi ndërmjet sipërfaqeve në dispozicion për kultivim dhe sipërfaqet e tokës që përdoret për të akomoduar një numër në rritje njerëzish. Zbulimi shkencor i teknologjisë së rekombinimit të ADN-së ka bërë të mundur manipulimin e përbërjes gjenetike të organizmave, duke prodhuar kultura rezistente ndaj ndikimeve klimatike, si dhe herbicideve dhe insekticideve të përdorura në kontrollin e barërave të këqija dhe dëmtuesve. Për shembull, duke parandaluar rritjen barërave të këqija, lejohet më shumë hapësirë për të kultivuar bimë. ${ }^{6}$

Nevoja për aplikimin e teknologjisë së MGJ në prodhimin bujqësor është sigurisht më e larta në Afrikë dhe Azinë Jugore, për shkak të problemit të madh të kequshqyerjes në mesin e popullatës. Përveç ushqimit të pamjaftueshëm, ka gjithashtu një nevojë për prodhimin e ushqimit me një përbërje të lartë të vlerave ushqyese. Thatësira, ujitja e kufizuar, tokat jo produktive, dëmtuesit dhe sëmundjet e kulturave janë arsyet kryesore për aplikimin e metodave të inxhinierisë gjenetike. Duke marrë parasysh përfitimet që kjo teknologji mund të sjellë, këto vende kanë dhënë mbështetje të plotë për zbatimin e saj në kultivimin e kulturave bujqësore. ${ }^{7}$

Shfaqja e ushqimit të modifikuar gjenetikisht ka krijuar pasiguri në botën, ndarjen sociale dhe etike. Studiuesit mbështesin se zhvillimi i teknologjisë së rekombinimit të ADN-së ka përmirësuar produktivitetin e bimëve dhe ofron një zgjidhje për problemin e ushqimit të pamjaftueshëm në dispozicion për popullsinë e botës. Nga ana tjetër, ambientalistët paralajmërojnë se mund të ndodhë një transformim i plotë i ekosistemit dhe prishja e ekuilibrit natyror. Konsumatorët janë të shqetësuar në përgjithësi se rezistenca ndaj antibiotikëve, reaksione alergjike dhe toksiciteti mund të zhvillohet.

Ka shumë diskutime në botë lidhur me prodhimin dhe konsumin e ushqimit të modifikuar gjenetikisht, pasiguria dhe shqetësimi janë në një masë të madhe të lidhura me efektet e mundshme negative të kulturave gjenetikisht të modifikuara në shëndetin e njeriut. ${ }^{2}$ Shkencëtarët besojnë se mosmarrëveshjet në lidhje me ushqimin e modifikuar gjenetikisht janë kryesisht pasojë e njohjes së pamjaftueshme të inxhinierisë gjenetike dhe një qëndrimi negativ ndaj asaj që është e panjohur. ${ }^{8}$ 
Ndërsa pjesa tjetër e botës kërkon të kuptojë dhe të pranojë përfitimet e aplikimit të modifikimeve gjenetike në organizma të ndryshëm, Bashkimi Evropian vë në pah disavantazhet e konsumimit të ushqimeve që përmbajnë ose kanë origjinën nga OMGJ. Ky skepticizëm evropian i UMGJ ngadalëson kërkimin dhe zhvillimin e mëtejshëm të teknologjive të reja në industrinë ushqimore. ${ }^{9}$

Është përgjithësisht e pranuar që para komercializimit, çdo ushqim MG duhet t'i nënshtrohet procedurave për vlerësimin e sigurisë dhe rrezikut. Sot, metoda e krahasimit me bimë të tjera me karakteristika të ngjashme përdoret për të vlerësuar sigurinë dhe rrezikun e kulturave gjenetikisht të modifikuara, duke u përpjekur për të demonstruar se të korrat MGJ janë të sigurta për konsumatorët dhe mjedisin. ${ }^{10}$

\subsection{Organizmat e modifikuar gjenetikisht}

Organizmat e modifikuar gjenetikisht janë organizma (bimë, kafshë ose mikroorganizma) materiali gjenetik i të cilëve është ndryshuar duke hyrë në një ose më shumë gjene duke përdorur teknika të inxhinierisë gjenetike. ${ }^{3}$

\subsubsection{Bimët e modifikuara gjenetikisht}

Bimët MGJ janë organizma, gjenoma e të cilave është ndryshuar nga transferimi i një ose më shumë gjeneve, për të shprehur karakteristika të rëndësishme që do të kontribuojnë në arritjen e rendimenteve më të larta, përbërjen më të mirë ushqyese dhe rezistencën ndaj herbicideve dhe insekticideve. Si ushqimi kryesor në botë, organizmat janë modifikimet gjenetike më të përshtatshme dhe konsiderohen si bio-objektet kryesore. ${ }^{11}$

Sidoqoftë, rritja dhe riprodhimi i bimëve ndikohet shumë nga stresi abiotik, siç janë thatësira, ndryshimet e kripësisë dhe temperaturës. Ndryshimi aktual i klimës ndikon në masë të madhe sasinë e rendimenteve të bimëve në mbarë botën. Ftohtësia ekstreme, ngrohtësia dhe rritja e kripshmërisë rezultojnë në ndryshime strukturore, molekulare, biokimike dhe fiziologjike, duke çuar në shqetësim të rritjes dhe riprodhimit të bimëve. Me qëllim të dizajnimit të bimëve gjenetikisht të qëndrueshme ndaj stresit abiotik, teknologjia e ADN-së rekombinante përdor molekulat e kodimit gjenin që përfshihen në mbrojtjen natyrore të bimëve kundër ndikimeve të jashtme të padëshirueshme. ${ }^{12} \mathrm{Një} \mathrm{problem} \mathrm{tjetër} \mathrm{që} \mathrm{ndikon} \mathrm{në} \mathrm{mënyrë} \mathrm{të} \mathrm{konsiderueshme}$ rendimentin e bimëve është stresi biotik, d.m.th. Sulmi i llojeve të ndryshme të patogjenëve dhe insekteve në kulturat bimore, gjë që ndikon shumë në prodhimin e tyre. Duke futur gjenet që kodojnë proteinat insekticide nga Bacillus thuringiensis, është arritur rezistenca ndaj llojeve të ndryshme të dëmtuesve. ${ }^{11}$

Bimët janë të pasura me vitamina dhe përbërës ushqyes të ndryshëm që mundësojnë një dietë të shëndetshme për njerëzit dhe kafshët. Megjithatë, ata nuk mund të përmbushin kërkesat $\mathrm{e}$ përgjithshme ditore për futjen e lëndëve ushqyese të caktuara. Ky fakt, në veçanti, është një problem në vendet ku të lashtat ndikohen nga ndikimet e ndryshme klimatike, ndërsa dieta e popullatës bazohet kryesisht në drithërat. Metodat e inxhinierisë gjenetike në këtë drejtim 
mund të ofrojnë një zgjidhje, kultivimin e bimëve rezistente ndaj stresit abiotik dhe biotik, përmes biofortifikimin të përbërësve ushqyesve thelbësorë për ruajtjen e shëndetit. ${ }^{13}$

\subsubsection{Ushqimet e modifikuara gjenetike}

Ushqimi i modifikuar gjenetikisht (UMGJ) është përcaktuar si ushqim që përmban ose rrjedh nga organizmat e modifikuar gjenetikisht (OMGJ). ${ }^{2}$ Termi ushqim ka të bëjë me çdo substancë që plotëson nevojat energjetike dhe ushqyese të organizmit. Bimët, si burimi kryesor dhe më i madh i ushqimit në botë, përbëjnë bazën e një piramide ushqimore. Prandaj, zhvillimi dhe zbatimi i metodave të inxhinierisë gjenetike në bimë dhe vlerësimi i rrezikut të përdorimit të tyre në të ushqyerit janë të një rëndësie të madhe për ruajtjen e shëndetit të konsumatorëve, biodiversitetit dhe ekosistemeve.

Një burim tjetër i rëndësishëm ushqimi janë kafshët, ose ushqimet e fituara nga kultivimi i tyre, siç janë qumështi, mishi, vezët, mjalti etj. Ushqimet që janë burim i mikroorganizmave është një shtesë e ushqimeve bazë dhe shërbejnë për të përmirësuar ngjyrën, shijen, erën, strukturën dhe ruajtjen e ushqimeve për një periudhë të gjatë kohore. ${ }^{13}$

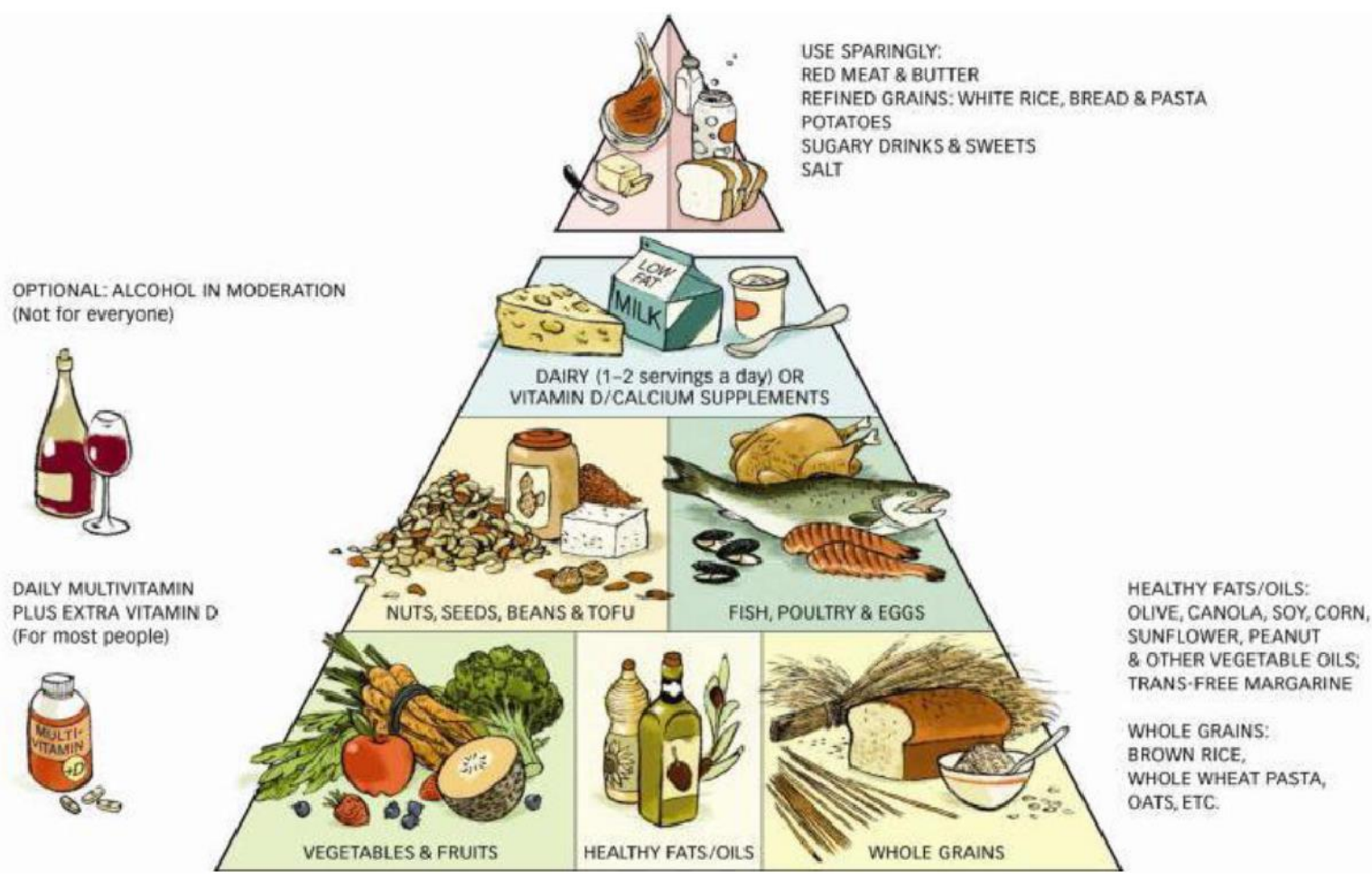

FOTO 1. Piramida e ushqimit

Popullsia në rritje paraqet një sfidë të madhe për industrinë ushqimore, e cila ka një detyrë të rëndësishme për të prodhuar ushqim të mjaftueshëm për konsumatorët. Kur është fjala për prodhimin botëror, në qendër të vëmendjes janë katër ushqimet esenciale të orizit, misrit, grurit dhe sojeve. Shkencëtarët besojnë se deri në vitin 2050 nevoja për këto ushqime do të jetë rreth $87 \%$ më e lartë. ${ }^{15}$ 


\subsection{Hyrje në treg e ushqimeve të modifikuara gjenetike}

Në vitin 1983, një grup shkencëtarësh kryen transferimin e gjenit bakterial në bimë, me të cilën u krijua bima e modifikuar gjenetikisht në bimën e duhanit, e cila ishte rezistente ndaj antibiotikëve. Pas kësaj, testet e para zyrtare të bimëve të modifikuara gjenetikisht u ndoqën për të shqyrtuar zgjidhjet e problemeve të mëparshme me bimët në rritje, mungesën e ushqimit në botë dhe prodhimin e ushqimeve më të shëndetshme dhe me vlera të larat ushqyese. ${ }^{11}$

Në vitin 1994, bima e parë e domate e modifikuar gjenetikisht u vendos në treg nën emrin "Flavr Savr", tipari kryesor i të cilit ishte pjekja e mirëfilltë e prodhimit. ${ }^{21}$ Shkencëtarët kanë treguar se maturimi i domates, i shoqëruar nga degradimi i pektinës në mur qelizor, është pasojë e aktivitetit të enzimës poligalakturonazë. Domate e parë MGJ kishte një gjen të poligalactic antisense i inkorporuar, i cili bllokon shprehjen e gjeneve të interesit. Ndalimi i pektinit rezultoi në parandalimin e zbutjes së përshpejtuar të frutit, d.m.th. arritjen e maturimit të vonuar. ${ }^{3}$

Në vitet në vijim, u përcoll zgjerimi i prodhimit të një numri në rritje të bimëve të modifikuara gjenetikisht, kështu që deri në vitin 2011 mbi 148 milionë hektarë sipërfaqe do të mbuloheshin nga kulturat e modifikuara gjenetikisht. Të lashtat që më së shpeshti që ishin të modifikuara gjenetikisht misri (Zea mays L.), soja (Glycine max L.), pambuku (Gossypium hirsutum L. Merr.) dhe rrepa vajore (Brassica napus L.). Përveç kësaj, gjithashtu ishin shumë të rëndësishme kulturat si orizi i modifikuar gjenetikisht (Oryza sativa L.), patatet (Solanum tuberosum L.), luzern-jonxha(Medicago sativa L.) dhe papaja (Carica papaya L.).

Karakteristikat e kulturave të modifikuara gjenetikisht u përpoqën të arrijnë, para së gjithash, tolerancën ndaj herbicideve të tilla si glifosati dhe glufosinati, dhe rezistenca ndaj insekteve dhe viruseve. Përveç kësaj, pas 23 viteve të ushqimeve gjenetikisht të modifikuara në treg, janë arritur edhe karakteristika të tjera, siç janë rezistenca e sëmundjes, cilësia më e mirë e produkteve, toleranca ndaj stresit abiotik dhe rritja e prodhimit të bimëve. ${ }^{16}$ Zhvillimi i kësaj teknologjie ka mundësuar gjithashtu prodhimin e kulturave me një përmbajtje më të madhe të komponentit të interesit, siç janë vitaminat, procesin e bio-stabilizimit në kokrra. Biofortifikimi është veçanërisht i rëndësishëm për drithërat, sepse drithërat e tyre nuk prodhojnë sasi të mjaftueshme të përbërësve ushqimore të rëndësishme. ${ }^{17}$

Tabela 1. Pasqyrë e katër gjeneratave të kulturave gjenetikisht të modifikuara18

\begin{tabular}{|l|l|l|}
\hline Gjenerata e parë & Gjenerata e dytë & Gjenerata e tretë \\
\hline
\end{tabular}




\begin{tabular}{|l|l|l|}
\hline $\begin{array}{l}\text { Toleranca herbicide: } \\
\text { a) Glyphosate (misri, soja, } \\
\text { pambuku, rrepa vajore } \\
\text { dhe panxhar sheqeri) }\end{array}$ & $\begin{array}{l}\text { Karakteristikat e modifikuara të } \\
\text { prodhimit, biofrtifikimi }\end{array}$ & $\begin{array}{l}\text { rezistenca ndaj kripërave të } \\
\text { tokës, rezistenca ndaj } \\
\text { metaleve në tokë }\end{array}$ \\
\hline $\begin{array}{l}\text { b) Glufosinat (misri, } \\
\text { pambuku soje, luledielli, } \\
\text { domate, gruri) }\end{array}$ & Maturimi i vonuar (domate) & Rezistenca ndaj thatësirës \\
\hline $\begin{array}{l}\text { Rezistenca ndaj insekteve: } \\
\text { Bacillus thuringiensis - Cry } \\
\text { gjen }\end{array}$ & $\begin{array}{l}\text { Përbërja e modifikuar (orizi i } \\
\text { artë) }\end{array}$ & $\begin{array}{l}\text { Prodhimi i vaksinave dhe } \\
\text { ilaçeve në bimë }\end{array}$ \\
\hline
\end{tabular}

Bimët e modifikuara gjenetikisht, të cilat janë të rëndësishme në të ushqyerit njerëzor, kanë arritur sukses të madh tregtar, por zhvillimi i kafshëve të modifikuara gjenetikisht nuk duhet të neglizhohet, gjë që është një mundësi e re për biomedicinë. Një shembull i përdorimit të inxhinierisë gjenetike në kafshë është shprehja e proteinës së gjëndrës së qumështit tek gjedhit për prodhimin e qumështit me një përbërje të përmirësuar, e cila mund të sjellë përfitime për shëndetin e njeriut. ${ }^{19}$

Që nga futja e ushqimeve të modifikuara gjenetikisht në treg deri më tani, 26 kultura të modifikuara gjenetikisht janë miratuar në mbarë botën për zhvillim, të ushqyerit e njerëzve dhe kafshëve. Duke u përqendruar në teknologjinë e re të kultivimit të bimëve, një numër në rritje i vendeve kanë treguar një interes për kultivimin e bimëve në një mënyrë të tillë.

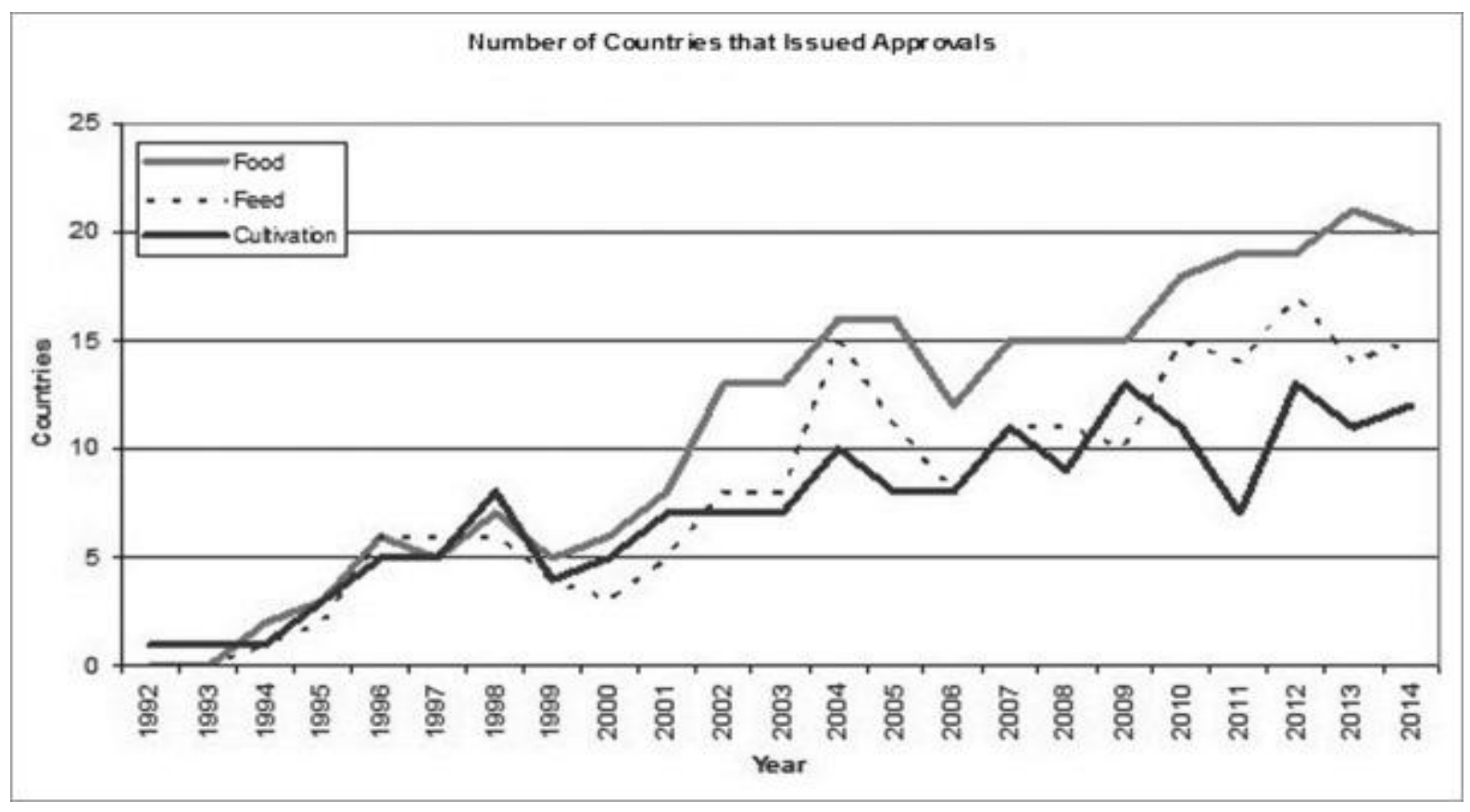

Figura 1. Numri i vendeve që kanë lëshuar miratimin për kulturat e modifikuara gjenetikisht

Siç tregohet në Figurën 1, numri i vendeve që kanë miratuara OMGJ-të është rritur gradualisht në mbarë botën. Në vitin 2012, rritja më e madhe u regjistrua, me 13 vende që ranë dakord të pranonin teknologjinë e re të kultivimit. Kulturat MGJ që më së shumti u lejuan në shumicën 
e vendeve ishin misri, soja, pambuku dhe rrepa vajore. Kur është fjala për numrin e aktiviteteve transgjenike në periudhën nga viti 1992 deri në 2014, për bimë të caktuar për ushqimin e njerëzve dhe të kafshëve, misri është në krye me 137 ngjarje transgjenike. Pas misrit, ndiqni pambuk, patate, rrepa vajore, soje, etj.

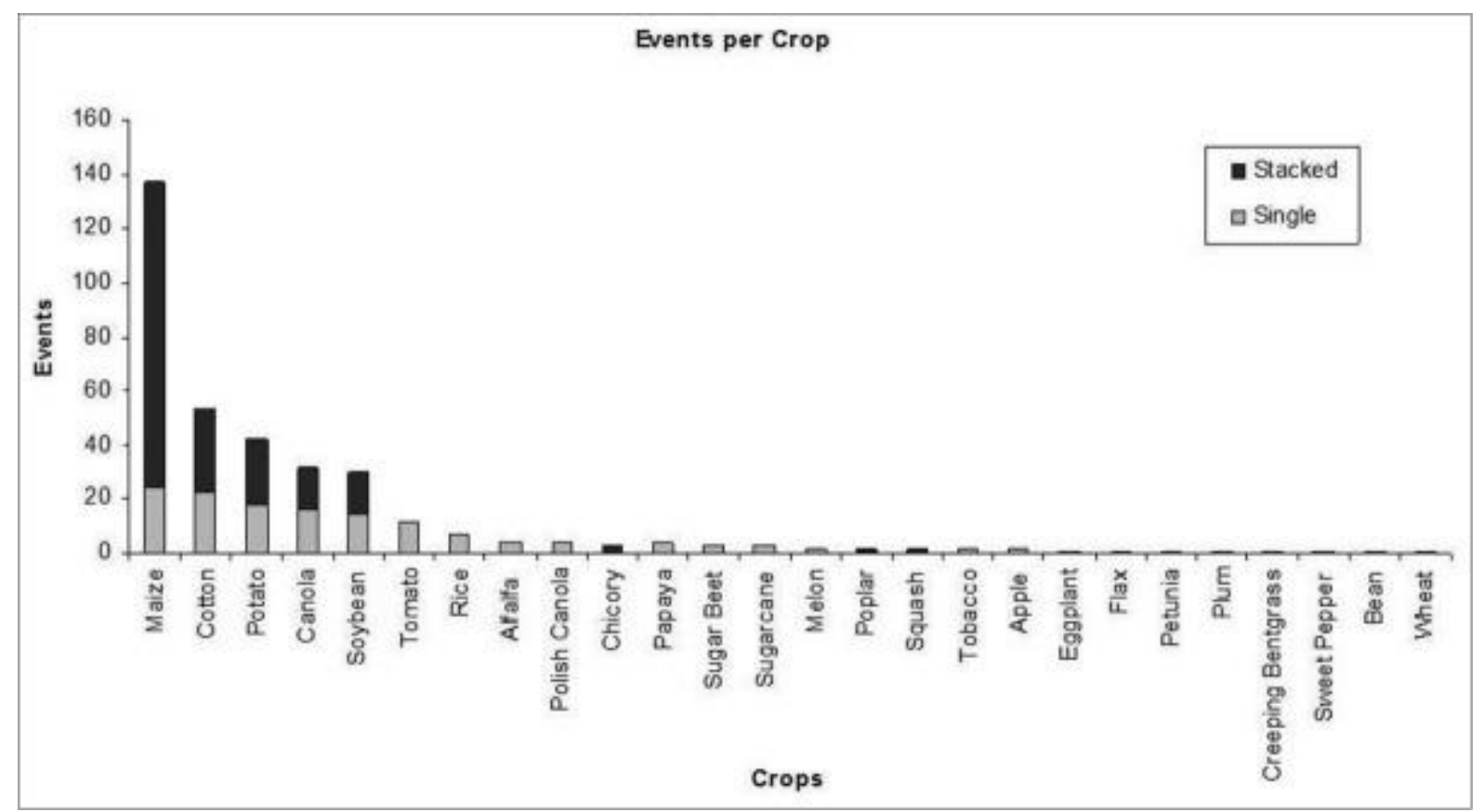

Figura 2. Numri i ngjarjeve transgjenike në 26 kulturat e miratuara për të ushqyerit ${ }^{16}$

Të dhënat më të fundit tregojnë një numër në rritje të aktiviteteve transgjenike në kulturat e përmendura. Misri është ende në krye, me 229 ngjarje transgjenike deri tani. Shtetet e Bashkuara kanë numrin më të madh të kulturave, më saktësisht 198 nga të cilat janë kryesisht misri dhe patatet. Bashkimi Evropian numëron 104 ngjarje, me pjesëmarrjen më të madhe në marrjen e ngjarjeve të misrit.

Karakteristikat e bimëve që janë më të kërkuar për të arritur metodat inxhinierike gjenetike janë toleranca ndaj herbicideve dhe rezistencës ndaj insekteve dhe metoda më e zakonshme është transformimi i ndërmjetësuar nga Agrobacterium. ${ }^{20}$ 


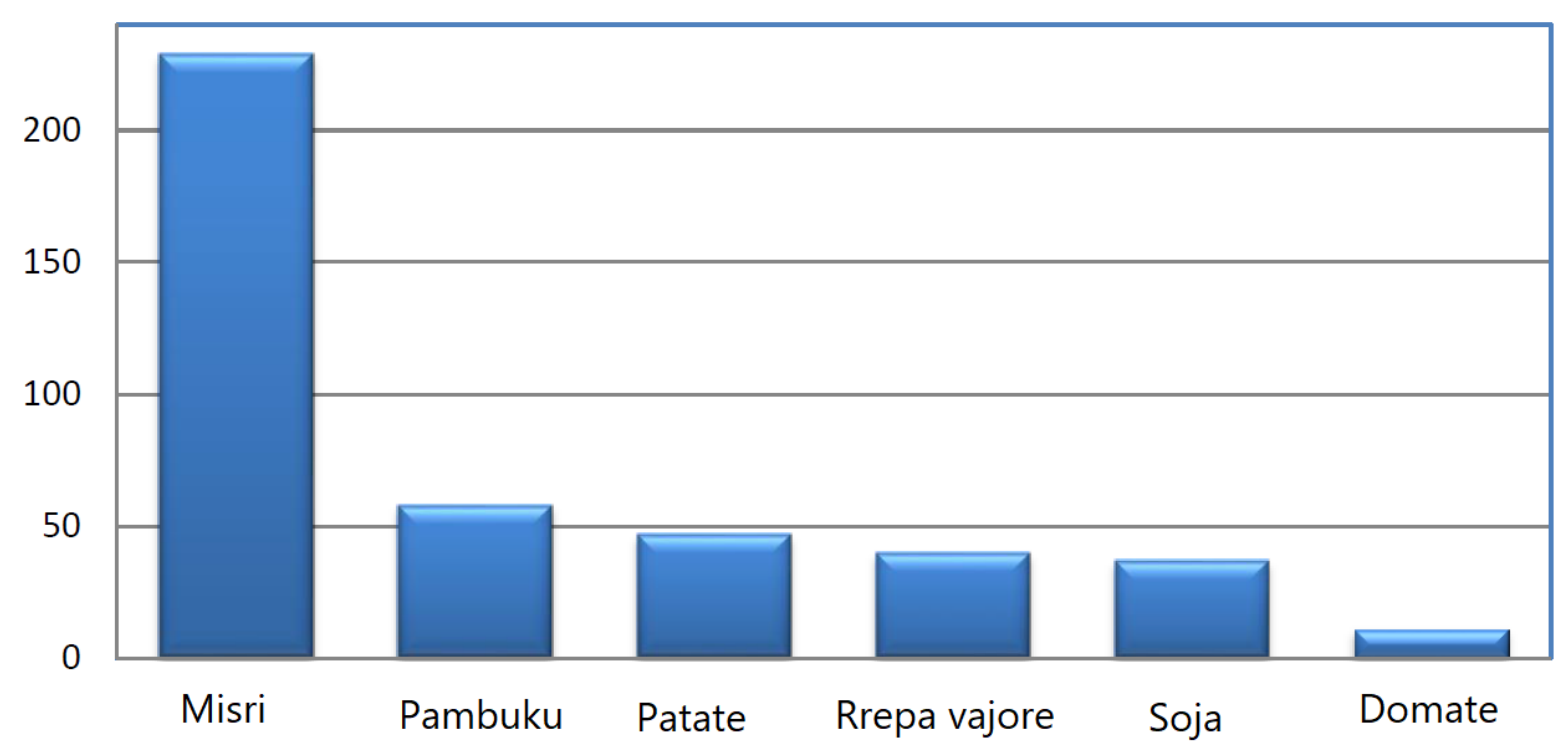

Figura 3. Numri i ngjarjeve transgjenike të miratuara në periudhën 1992 deri $2017^{20}$

\subsection{Llojet e ushqimeve të modifikuara gjenetikisht}

\subsubsection{Misri MGJ}

Misri (Zea mays L.) është një drithëra që prodhohet në sasi më të madhe në të gjithë botën. gjerësisht gjatë gjithë vitit. ${ }^{21}$ Duke pasur parasysh popullatën gjithnjë në rritje të botës, prodhimi i misrit MGJ do të jetë i një rëndësie të madhe në drejtim të arritjes së prodhimit më të lartë të ushqimit. ${ }^{22}$ Për këtë qëllim, është prodhuar misri me tolerancë ndaj herbicideve (misri MGJ-HT) është prodhuar për të përmirësuar kontrollin barërave të këqija dhe të marrin rendiment më të lartë të kulturave. ${ }^{23}$

Për shkak të defiçiencës së mikronutrientëve në ushqimin, vendet në zhvillim, prodhuan një varietet të veçantë të misrit MGJ me një përmbajtje të lartë të $\beta$-karotenit, askorbatit dhe folatit. Studimet në minj nuk treguan shenja të toksicitetit ose alergjen potencial. ${ }^{24}$

Prodhimet e misrit janë shumë të ndjeshëm ndaj dëmtimit të insekteve dhe përdorimi i tepruar i insekticideve çon në rritjen e kostove dhe ndikimeve të pafavorshme në shëndetin e njeriut dhe mjedisin. Prandaj, modifikimi gjenetik i misrit është kryer duke transferuar gjenin e bakterit të tokës Bacillus thuringiensis për të prodhuar një proteinë Bt për të shtypur efektin e dëmshëm të insekteve të misrit. ${ }^{25}$

\subsubsection{Soja MGJ}

Soja (Glycine max L.) është një bimë me rëndësi të madhe për ushqimin njerëzor, të pasur me proteina, vaj vegjetal dhe fitokimikate. Megjithatë, përmbytjet dhe thatësira kanë efekte tejet 
negative në prodhimin e sojës. ${ }^{26} \mathrm{Si}$ rezultat i ndjeshmërisë së thatësisë, është raportuar për zvogëlimin e prodhimit vjetor, duke rezultuar në humbje të mëdha. Për këtë qëllim, është realizuar transferimi i faktorit të transkriptimit (TFs, rezistent ndaj thatësirës. Ky proces ka rezultuar me rezistencë më të mirë të bimëve kundër ndikimeve të jashtme të pafavorshme, pa ndikuar në përbërjen ushqyese të kulturës. ${ }^{27}$

Për shkak se është shumë i rëndësishëm në të ushqyerin e kafshëve dhe njeriut, gjithashtu është një burim potencial për prodhimin e lëndëve djegëse biologjike të rinoveshme. ${ }^{28}$ Për të siguruar rendiment të lartë të sojës, për të përmbushur nevojat e ushqimit në botë, është e nevojshme të prodhohen varietete me cilësi të përmirësuar. ${ }^{29}$

Për të arritur rendimentet më të larta të sojeve, reduktimi i kostove të prodhimit për shkak të përdorimit të herbicideve të kontrollit të farërave, soji i nënshtrohet një sërë modifikimesh gjenetike. Këto modifikime përfshinin transferimin e gjenit të bakterit Agrobacterium tumefaciens për të arritur tolerancën ndaj herbicidit glyphosat, pastaj transferimin e gjenit të Bacillus thuringiensis, duke rezultuar në rezistencë ndaj insekteve. Kështu, soja është prodhuar me cilësi të përmirësuar dhe me prodhim më të lartë vjetor. ${ }^{30}$ Soja MGJ ka përmirësuar prodhimin e pijeve, vajit, miellit nga soja etj. Një veçori shumë e rëndësishme e sojës MGJ është rritja e përmbajtjes së acideve yndyrore të pangopura omega dhe acideve oleike që ulin nivelin e kolesterolit në njerëzit dhe zvogëlojnë rrezikun e sëmundjes kardiovaskulare. ${ }^{31}$

\subsubsection{Orizi MGJ}

ORIZI (Oryza sativa L.) është një përbërës kyç i ushqimit për ushqimin e njerëzve, veçanërisht në vendet e populluara. ${ }^{32}$ Ky ushqim është i ndjeshëm ndaj sëmundjeve të tilla si plasaritja e grurit të shkaktuara nga patogjenët e kërpudhave hemibiotrophic (Magnaporthe oryzae) ${ }^{33}$ dhe shfaqjen e njollave në bimë e shkaktuar nga patogjen, nga mbështjellsi i kokërrs duke prodhuar toksinën (Rhizoctonia solani). ${ }^{34}$ Këto sëmundje janë një nga pengesat kryesore për arritjen e rendimenteve të larta. ${ }^{35}$.

Vlera e ulët e mikronutrientëve është veçanërisht e theksuar në vendet ku drithërat janë burim kryesor i kalorive. Për këtë qëllim, është bërë biofortifikimi i korave të orizit për të rritur nivelet e mikronutrientëve në drithra. ${ }^{36}$ Kokra e orizit i është nënshtruar modifikimit gjenetik me qëllim të prodhimit të orizit përmbajtjes të lartë $\beta$-karotenit, një pararendës i vitaminës $A, i$ cili u quajt Golden Rice. ${ }^{37}$ Mungesa e vitaminës A është shkaku kryesor i çrregullimeve të funksioneve pamore, riprodhuese dhe të rritjes. ${ }^{38}$ Prodhimi i orizit transgjenik siguroi një nivel të lartë të $\beta$-karotenit në dietën e popullatës së paprivilegjuar. Studimet në Golden Rice dhe ushqime të tjera për $\beta$-karotenin kanë treguar se nuk ka dallim në efikasitetin e konvertimit $\beta$ karotenit në vitaminë A krahasuar me bimët e fituara nga metodat tradicionale tëkultivimit.

Instituti Ndërkombëtar për Studimin e Orizit (IRRI) ka konfirmuar se oriz i artë nuk do të ndikojë në biodiversitetin, nuk ekzistojnë barëra të këqija. Arsyeja për këtë është se orizi shumëzimin e realizon me vet pllenim dhe jo me shumëzim të kryqëzuar. ${ }^{39}$

\subsubsection{Gruri MGJ}


Gruri (Triticum aestivum L.) është bima kok;royore më e rëndësishme e përdorur në dietën e popullsisë së botës, dhe sipas sasisë së prodhuar gjatë vitit është e dyta, menjëherë pas misrit. Megjithatë, prodhimi global i grurit është nën ndikimin e ndryshimeve klimatike, thatësirës dhe dëmtuesve (kërpudhave dhe insekteve), gjë që çon në uljen e rendimenteve vjetore. Prandaj, bioteknologjia ofron një zgjidhje për prodhimin e varieteteve rezistente MGJ të grurit, e cila është e pranueshme ekonomikisht dhe ekologjikisht. ${ }^{40}$

Sasia e ushqimit në botë varet në masë të madhe nga disponueshmëria e drithërave. Gruri është shumë i rëndësishëm në këtë drejtim, sepse përmban gluten, i cili ndikon dukshëm në fryrjen e produkteve të miellit nga grurit. Gluteni i grurit është një përzierje e dy llojeve të proteinave, të cilat janë gliadin dhe glutenin. Problemi ndodh menjë pjesë të popullsisë që janë alergjisë ndaj glutenit të grurit, ku zhvillohet sëmundja e ndjeshmërisë (intoleranca) ndaj glutenit. ${ }^{41}$ Gliadin e aktivizon gjenin imun, duke shkaktuar kështu çlirimin e citokinës, gjë që mund të çojë në inflamacion kronik në trup. ${ }^{42}$

Për shkak të rritjes së numrit të njerëzve të ndjeshëm ndaj glutenit, bioteknologjia ka lejuar zhvillimin e grurit gjenetikisht të modifikuar me përmbajtje të ulët të gliadinës dhe zvogëlon aktivizimin e të citokinës. Studimet e kryera në minjtë nuk kanë treguar se gruri MGJ ka një ndikim negativ në shëndetin e njeriut. ${ }^{43}$

\subsection{Vlerësimi i sigurisë dhe rreziku i ushqimit të MGJ}

Vlerësimi i sigurisë dhe rrezikut të prodhimit dhe përdorimit të OMGJ-ve është i një rëndësie të madhe, sepse futja e gjeneve në një organizëm të caktuar, nuk është e mundur të dihet se cilat do të jenë efektet në shëndetin e njeriut, biodiversitetin dhe ekosistemet. Prandaj Codex Alimentarius ofron udhëzime të njohura ndërkombëtarisht për testimin e sigurisë dhe vlerësimin e rrezikut të ushqimeve OMGJ. Këto udhëzime përmbajnë disa kapituj, të cilat përfshijnë hapa për të shqyrtuar ushqimet e OMGJ-ve që vijnë nga bimët, kafshët dhe mikroorganizmat. ${ }^{44}$

Për shembull, vlerësohet nëse prodhimi gjenetik i prodhuar përfaqëson siguri ose rrezik për njerëzit, biodiversitetin, ekosistemin ose bujqësinë. Vlerësimi i rrezikut përfshin analizën dhe karakterizimin e rrezikut, vlerësimin e ekspozimit dhe përfundimisht përkufizimin e rrezikut. Vlerësimi i sigurisë përfshin të njëjtat hapa si vlerësimi i rrezikut, me dallimin se siguria përfaqëson mungesën e rrezikut.

Aktualisht, strategjia më e zakonshme është një qasje e synuar bazuar në konceptin e një vlerësimi krahasues të sigurisë. Thelbi i procedurës është krahasimi i bimës së prodhuar me metodat e inxhinierisë gjenetike, në krahasim me atë të fituar nga kultivimi tradicional. Me fjalë të tjera, krahasoni ekuivalencën e bimës së njëjtë, por rritet me metoda të ndryshme.

Në këtë mënyrë, bëhet një pasqyrë e dallimeve në nivelet fenotip-agronomike dhe molekulare, si dhe një vlerësim i përbërjes së lëndëve ushqyese. Nëse një dallim është identifikuar që mund të paraqesë rrezik, bëhet identifikimi i tij dhe vlerësimi i mëtejshëm i shfaqjes së efekteve të 
mundshme pozitive ose negative. Kjo pasohet nga klasifikimi i rrezikut, vlerësimi i ekspozimit dhe analiza e rrezikut. ${ }^{45}$

Vlerësimi i sigurisë dhe i rrezikut është i një rëndësie të madhe sepse gjenetika nuk është gjithmonë e parashikueshme. Është shumë e rëndësishme të monitorohet qëndrueshmëria e gjenotipit të organizmit të modifikuar dhe nëse organizmi MGJ ekspozon fenotipin e dëshiruar. ${ }^{46}$ Vëmendje e veçantë i është kushtuar vlerësimit të rrezikut të ushqimeve OMGJ për shëndetin e njeriut, për shkak të dyshimit për efektet afatshkurtra dhe afatgjata të tij në shëndet, siç është shfaqja e reaksioneve alergjike, sintezën e substancave toksike dhe zhvillimin e rezistencës ndaj antibiotikëve. ${ }^{47}$

\subsection{Ndikimi i bimëve të MGJ në kualitetin e ushqimit me origjinë shtazore}

Gjatë 30 viteve të fundit, ka pasur shumë përparime në përmirësimin e cilësisë së ushqimeve me origjinë shtazore, zhvillimin e bioteknologjisë, e cila ka bërë të mundur prodhimin e kulturave me një dietë të përmirësuar për kafshët. Kjo vlen veçanërisht për ushqimin me origjinë nga derrat, lopët dhe shpendët. Objektivat themelore janë përmirësimi i rritjes së kafshëve dhe përbërja e produkteve të fituara nga kultivimi i tyre. ${ }^{48}$ Për të marrë produkte cilësore me origjinë shtazore, pika e fillimit është prodhimi i ushqimit të sigurt dhe cilësor të kafshëve.

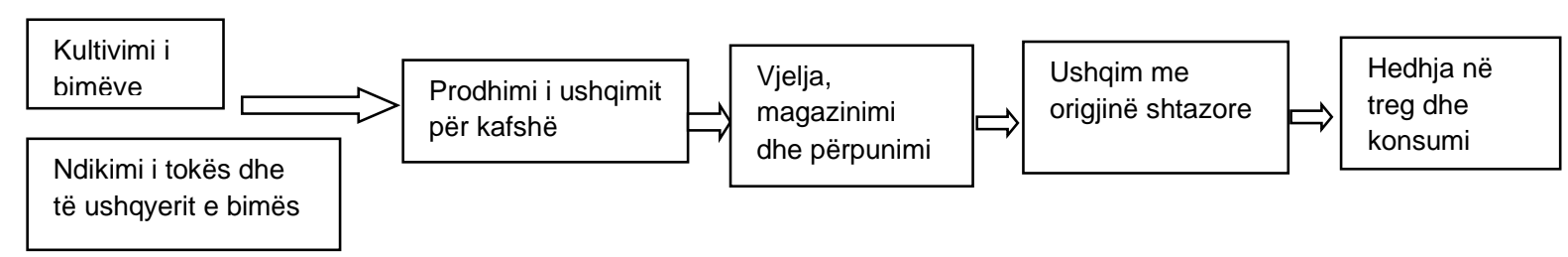

Figura 4. Kultivimi i bimëve si pika fillestare e zinxhirit ushqimor

Në dietën e njerëzve, është me rëndësi të madhe të konsumohen ushqime me origjinë shtazore, dhe më të rëndësishëm nga këto ushqime janë mishi, peshku, qumështi dhe vezët. Karakteristikat e tyre kryesore janë sigurimi i marrjes së mjaftueshme të ushqimit si proteina me cilësi të lartë, acide yndyrore esenciale dhe vitamina (p.sh. B12) dhe minerale (p.sh. hekuri dhe zinku) të domosdoshme për shëndetin e njerëzve. Për të siguruar një sasi të mjaftueshme të këtij ushqimi, qëllimi është rritja e rendimentit bujqësor të kulturave të përdorura për të ushqyerit dhe mbarështimin e kafshëve.

Cilësia e ushqimit për kafshët ka një ndikim të rëndësishëm në cilësinë dhe përbërjen e ushqimit të kafshëve, i cili përdoret në të ushqyerit e njerëzve. Para së gjithash, nëse përbërja ushqyese e ushqimit të kafshëve është e kënaqshme, atëherë ushqimet e përdorura nga popullata do të jenë më të mira. Përbërësit ushqyes, si acidet yndyrore, mineralet dhe vitaminat, kalojnë drejtpërdrejtë nga ushqimi që u jepet kafshëve tek ushqimet me origjinë shtazore.

Kequshqyerja në botë është shprehur gjerësisht, dhe arsyeja është mungesa e mikronutrientëve dhe marrja e pamjaftueshme e ushqimit me origjinë shtazore me përmbajtje të lartë të proteinave dhe yndyrës. Ndikimet e pafavorshme klimatike dhe faktorët tjerë që ndikojnë në 
kulturat e përdorura në ushqimin e kafshëve rezultojnë në cilësi të dobët të këtij ushqimi, i cili ka një ndikim të drejtpërdrejtë në cilësinë e ushqimit për njerëzit. Vlera e energjisë e produkteve ushqimore me origjinë shtazore në vitet $\mathrm{e}$ fundit ka qenë në rënie të konsiderueshme, prandaj ka qasje në teknologji të reja me qëllim të përmirësimit të cilësisë.

Janë analizuar për cilësinë e ushqimit të kafshëve, pas ushqyerjes së kafshëve me bimë të gjeneratës së parë të misrit MGJ, rrepë vajore dhe soje rezistente ndaj herbicideve dhe insekticideve. I njëjta hulumtim nuk ka treguar dallime në përbërje dhe cilësinë në lidhje me ushqimin e marrë nga kafshët e ushqyer me bimë të rritura natyrshëm. Për më tepër, u kryen testet e ndikimit të bimëve MGJ të gjeneratës së dytë, e cila karakterizohet nga ndryshime në përbërjen e bimëve në kuptimin e biofortifikimt, domethënë rritje të përmbajtjes së përbërësve me interesit. Është vërtetuar se ato mund të kontribuojnë në përmirësimin e përbërësve ushqyese tek ushqimit me origjinë shtazore. Një shembull i avantazheve të këtyre modifikimeve është futja e gjenit në misër, në mënyrë që të rritet përmbajtja e aminoacideve esenciale lizinë. Me këtë misër transgjenike janë ushqyer pula duke rezultuar në një rritje të peshës trupore, por jo një ndryshim në përbërjen e mishit të pulave. Një tjetër ngjarje e rëndësishme transgenike, futja e gjeneve në gjenomën e sojës, rezultoi në shprehjen e enzimeve të desaturazë, roli i të cilave është transformimin e acideve yndyrore të ngopura në të pangopura. Pulat e ushqyerjes me këtë sojë të MGJ rezultojnë në rritjen e përmbajtjes së acideve yndyrore të pangopura në mish pule. Në të njëjtën mënyrë, përbërja e qumështit, në kuptim të acideve yndyrore të pangopura, është marrë nga lopët e ushqyer me sojën MGJ.

Manipulimi gjenetik i bimëve në mënyrë që të përmirësohet të ushqyerit e kafshëve nuk është shumë i rëndësishëm për kafshët, sa që është për njerëzit që konsumojnë këtë ushqim. Duke pasur parasysh se modifikimet gjenetike në bimë mund të prodhojnë ushqime të pasura ushqyese me origjinë shtazore, kjo konsiderohet të jetë një mënyrë efektive për të luftuar kequshqyerjen në botë. Efektet negative të ushqimeve me origjinë shtazore, në sfond të së cilave janë të pranishme OMGJ, nuk janë provuar, kështu që ky ushqim mund të jetë i dobishëm për fermerët dhe popullatën. ${ }^{49}$

\subsection{Përparësitë e mundshme dhe disavantazhet e modifikimit gjenetik për bujqësinë}

Kultivimi tradicional i bimëve dhe përparimet në bujqësi duke përdorur kimikate për ruajtjen e të lashtave kanë kontribuar shumë në përmirësimin e rendimentit. Përdorimi i kimikateve për kontrollin e barërave të këqija dhe dëmtuesve rezultoi me kosto të larta për fermerët dhe gjithashtu shkaktoi ndotje të tokës dhe të ujërave. ${ }^{6}$

Në mënyrë që të rritet rendimenti bujqësor, të zvogëlohet kostoja e kultivimit dhe të përmirësohet siguria ushqimore, janë zhvilluar teknologji të ndryshme dhe bioteknologjia e bimëve është veçanërisht e rëndësishme. ${ }^{50}$ Rreth 50,000 bimë që konsumohen janë rritur në mbarë botën, por sipas FAO-s, ushqimet më të rëndësishme për një konsum të mjaftueshëm ditor janë oriz, misër dhe grurë.

Për shkak të shumë efekteve negative të stresit biotik dhe abiotik në bimët, ka ardhur deri tek ulja e rendimentit tek këto kultura. ${ }^{51}$ Duke pasur parasysh se përdorimi i metodave të 
inxhinierisë gjenetike jep rendimentet dukshëm më të larta, kjo ishte një nga arsyet kryesore për miratimin e tij në mesin e fermerëve. ${ }^{52}$

Kur mbjellin bimë, një nga problemet kryesore është rritja e barërave të këqija që u marrin bimëve hapësirën, ujin dhe mineralet nga bimët. Për shumë vite fermerët kanë luftuar me barërat e këqija me lërim të thellë, gjë që ka çuar në shterimin e tokës dhe lirimin e dyoksidit të karbonit, por jo parandalimin e prodhimit të farërave të mëtejshme. Prandaj, një mënyrë tjetër ishte përdorimi i herbicideve si glyphosate dhe glufosinate për të luftuar rritjen e farërave të këqija. Kulturat MGJ rezistente ndaj herbicideve u kanë mundësuar fermerëve të mbështeten shumë në përdorimin e herbicidit për të kontrolluar barërat e këqija. ${ }^{53}$

Përveç kursimeve ekonomike, shumë fermerë përmendin përfitime të tjera të adoptimit të kultivimit të kulturave gjenetikisht të modifikuara, të tilla si kursimi i kohës, lehtësia e përdorimit dhe organizimi më i mirë i planifikimit. ${ }^{54}$ Përdorimi afatgjatë i glyphosate në tokë ku kulturat tolerante ndaj herbicideve janë rritur gjerësisht ka çuar në zhvillimin e barërave të këqij tolerantë ndaj herbicideve. Rritja e barërave të këqija kërkonte një përdorim të rritur të këtyre tretësirave në mënyrë të përsëritur. Ky fenomen i atribuohet përdorimit të vetëm një herbicid, sidomos për glifosatin, pa kombinimin e kimikateve të tjera. ${ }^{52}$

Llojet e ndryshme të dëmtuesve shkatërrojnë dhe parandalojnë e shumë bimëve me të cilat ushqehen. Prandaj, fermerët janë të detyruar të përdorin insekticide të ndryshme, të cilat çojnë në kosto të reja dhe ndikim negativ në agrobiznes.

Zhvillimi i bioteknologjisë nënkuptonte kultivimin e kulturave gjenetikisht të modifikuara rezistente ndaj dëmtuesve. Për bujqësinë, kjo nënkuptonte përdorimin e reduktuar të insekticideve në kontrollin e dëmtuesve dhe për rrjedhojë zvogëlimin e shpenzimeve, gjë që është një avantazh i madh. Prodhimi i bimëve MGJ rezistente ndaj insekteve përfshin futjen e gjeneve nga Bacillus thuringiensis në bimën e dëshiruar. Këto gjene kodojnë proteina që janë provuar të jenë toksike ndaj insekteve. Në këtë mënyrë arrihet rezistencë ndaj llojeve të ndryshme të dëmtuesve. Studimet e reja kanë treguar avantazhe të tjera të rëndësishme të këtij modifikimi, të tilla si rezistenca ndaj insekteve të ndryshme, detoksifikimit të metaleve të rënda të ndryshme, nxitjen e rritjes së bimëve, etj. ${ }^{55}$ Përveç problemeve me rezistencë ndaj herbicidit për shkak të zhdukjes së barërave të këqija dhe ndikimit negativ të insekteve, viruseve dhe kërpudhave në kulturat bujqësore, fermerët shpesh përballen me problemin e acareve të papritura. Ky fenomen mund të shkatërrojë një sasi të madhe të të ardhurave dhe të shkaktojë dëme të mëdha. Prandaj, bioteknologjia ofron një zgjidhje duke futur gjene antifriz (AFP) nga peshqit që jetojnë në ujërat e ftohtë në bimë që janë të ndjeshme ndaj temperaturave të ulëta. Kjo qasje i mundësoi bimëve, si patatet dhe duhanin, të arrinin në temperatura që përndryshe nuk do të ishin në gjendje të mbijetonin. Përveç kësaj, temperaturat jashtëzakonisht të larta kanë një efekt të kundërt në rendimentet e kulture, pasi ato mund të çojnë në denatyrimin e proteinave të qelizave. Si rezultat, krijohet stresi i proteinave që mbron qelizën nga ndikimet negative të nxehtësisë.

Fermerët gjithashtu ballafaqohen me problemin e hapsirave të tokës bujqësore, pasi gjithnjë e më shumë tokë përdoret për tu banuar nga popullsia. Është një sfidë e madhe për të rritur bimët 
në zona që nuk janë të përshtatshme për rritje, si toka të thata me sasi të lartë kripe. Përqendrimi i lartë i kripës parandalon aktivitetin osmotik të rrënjës së bimës, e cila ka një efekt toksik në rritjen e bimës. Zgjidhja ofron bioteknologji duke projektuar bimë rezistente ndaj thatësirës dhe kripërave. Në fund të fundit, kultivimi i bimëve gjenetikisht të modifikuara me siguri ka më shumë përfitime për bujqësinë, pasi kjo zvogëlon kostot dhe kohën e përpunimit, jep prodhimtari më të larta, në mënyrë që më shumë ushqime të shpërndahen në popullatë. ${ }^{3}$

Një nga metodat më të përfolura pa dyshim që është rasti i orizit të artë. Një artikull i famshëm i shkruar nga Angelika Hilbeck and Hans Herren thotë: miliona janë harxhuar për këtë projekt dhe askush nuk ka përfituar, ata fajsojnë për dështimin e orizit të modifikuar gjenetikisht? Faktet më interesante që ky artikull ofron janë se ende nuk ka oriz që përmban vitamin A pavarësisht burimeve të disponueshme, mbështetje konceputale shumë e diskutueshme, përpjekje epike, mendësi koloniale etj. Kurse artikulli i vitit 2018 nga Allison Wilson, $\mathrm{PhD}$ and Jonathan Latham, PhD shpjegon se si FDA ka deklaruar se orizi i artë nuk ofron asnjë vlerë nutritive për të cilat është destinuar. ${ }^{56}$

\subsubsection{Degradimi i shpejtë i $\beta$-karotenit tek orizi i artë}

Në të njëjtin memorandum FDA gjithashtu deklaron: "IRRI pranoi se pret që marrja e dietave aktuale të jetë më e ulët duke pasur parasysh ... që nivelet e $\beta$-karotenit në ushqimin që përmbajnë oriz GR2E do të binin me kalimin e kohës për shkak të ruajtjes ...”

Degradimi i beta-karotenit gjatë ruajtjes është një problem që mund të dëshmojë edhe më shqetësues për përfitimet ushqyese të propozuara të Orizit të Artë sesa nivelet e tij fillestare të ulëta. Pa u vënë re nga media, një punim i vitit 2017 i botuar në Gazetën e Kimisë Bujqësore dhe Ushqimore raportoi që përmbajtja beta-karotene e Golden Rice GR2E gjatë korrjes është jetëshkurtër. Ky studim zbuloi se orizi i Artë ruajti vetëm $60 \%$ të niveleve të tij origjinale betacarotene pas 3 javësh ruajtje dhe vetëm 13\% pas 10 javësh. Shpjegimi i qartë është se betacarotene në Rajs Artë është e paqëndrueshme në prani të oksigjenit. Kështu, në kushte normale të depozitimit, beta-karoteni në kokrrat e Rajs së Artë do të degjenerohet shpejt. Nën bujqësinë tropikale, deponimin dhe kushtet shtëpiake, degradimi mund të jetë akoma më i shpejtë. ${ }^{57}$

\subsubsection{Ndikimi i OMGJ-ve për biodiversitetin dhe ekosistemin}

Së pari, toksiciteti është një çështje e madhe për pesticidet kimike dhe herbicideve, të përdorura zakonisht me OMGJ, përveç toksicitetit të natyrshëm të këtyre ndaj bimëve. OMGJ-të mund të jenë toksike për organizmat non-target, bletët dhe fluturat që janë shembujt më të diskutuar aktualisht. Bletët janë jashtëzakonisht të rëndësishme për pllenim të shumë kulturave ushqimore, por për fat të keq janë jashtëzakonisht të rrezikuara nga teknikat bashkëkohore bujqësore, të tilla si kulturat gjenetikisht të modifikuara. Fluturat monarke janë posaçërisht në rrezik nga bimët e misrit që rrjedhin nga OMGJ-të. Përveç bletëve dhe fluturave, zogjtë janë gjithashtu në rrezik nga pesticidet, dhe punojnë si agjentë të kontrollit biologjik . 
Sa iu përket bletëve, dëmtimi i tyre rrezikon seriozisht jetën e të gjithë organizmave të gjallë. Ato jo vetëm që janë në rrezik nga agro-kultura modern dhe teknikat bashkëkohore e globalizmi, më e keqja, disa prej tyre tanimë zyrtarisht konsiderohen specie në zhdukje.

Ruajtja e biodiversitetit, është me rëndësi të veçantë për mbrojtjen e të gjithë ekosistemit. Kultivimi i kulturave gjenetikisht të modifikuara shkakton paqartësi të ruajtjes së biodiversitetit dhe stabilitetit të ekosistemit. Në këtë mënyrë manipulon proceset natyrore, të cilat janë zhvilluar për shumë vite. Shumëzimi i kryqëzuar i bimëve të modifikuara gjenetikisht me bimët e egra mund të shkaktojnë efekte të dëmshme në biodiversitetin. Gjithashtu, manifestimi i fenotipit të një bime të modifikuar, në kontakt me mjedisin, mund të çojë në pasoja negative.

Studimet kanë treguar se numri i insekteve të dobishme për bimët është dukshëm në rënie, ndërsa numri i dëmtuesve rritet. Mbrojtja dhe ruajtja e larmisë biologjike u miratua në vitin 1993 në Konventën për Diversitetin Biologjik (CBD), dhe më pas u konfirmua me Protokollin e Cartageenes në vitin 2003. Në këtë mënyrë, aktivizohet rrjedha e informacionit mbi organizmat e gjallë të modifikuar dhe ndikimi i tyre në biodiversitetin. Kjo ka çuar në një komunikim më të mirë midis vendeve, sa i përket vendimit për të pranuar ose refuzuar importet e kulturave të modifikuara gjenetikisht.

Rritja e sipërfaqeve të mbjella me kultura të modifikuara gjenetikisht ka një ndikim të rëndësishëm në degradimin e biodiversitetit. Kulturat MGJ që janë komercializuar deri më sot janë kryesisht kultura që tregojnë tolerancë ndaj herbicidit dhe rezistencës së insekteve ose që kanë të dyja karakteristikat. Përdorimi i tepërt i herbicideve në luftën kundër barërave të këqija dhe insekticideve për të mbrojtur kundër dëmtuesve ka një ndikim të rëndësishëm në humbjen e biodiversitetit. Konsiderohet se janë bimë të padëshirueshme që marrin hapësirë dhe pengojnë rritjen e bimëve të kultivuara që janë të rëndësishme për agrobiznesin. Përkundër kësaj, barërat e këqija janë pjesë e biodiversitetit natyror dhe si të tilla ndërveprojnë me bimët e kultivuar në shkëmbimin e lëndëve ushqyese. Gjithashtu mbron tokën nga nxehtësia e diellit dhe parandalon avullimin, dhe mbron bimën nga kërpudhat dhe dëmtuesit. Çdo shtrembërim i diversitetit natyror ndikon në masë të madhe në të gjithë zinxhirin e ushqimit. Megjithëse barërat ka një efekt pozitiv në bimët e kultivuara, fermerët ende përdorin herbicide për të patur tokë më të punueshme dhe rendiment më të lartë.

Efekti negativ i bimëve gjenetikisht të modifikuara në biodiversitetin dhe mjedisin gjithashtu mund të manifestohet përmes mikroorganizmave të tokës që kanë aftësinë për të marrë bimë transgenike të MGJ përmes transferimit horizontal të gjeneve. Gjatë prodhimit të bimëve MGJ, shpesh përdoren gjene selektive të markuar (SMGs), të cilët përzgjedhin selektivisht qelizën në të cilën do të bëhet transferimi i gjeneve. Si SMGs, antibiotikët e rezistencës bakteriale të gjenit përdoren më së shpeshti, dhe rrjedhimisht mund të shkaktohen përhapja e tyre në mjedis dhe ndikimi në bimë të tjera. ${ }^{58}$

Disa lloje insektesh me anë të reaksionit të reduktimit, oksidimit ose të konjugimit neutralizojnë toksinat, duke parandaluar efektet e tyre të dëmshme mbi bimët dhe mjedisin. Transferimi i gjenit nga Bacillus thuringiensis tek bimët, që rezulton në shprehjen e proteinave 
Cry, është metoda kryesore e inxhinierisë gjenetike në luftën kundër insekteve të dëmshme. Megjithatë, disa studime kanë demonstruar fillimin e rezistencës së insekteve ndaj Bt. Aftësia e një insekti për të zhvilluar rezistencën mund të çojë në dështim në prodhimin e bimëve Bt. Nga ana tjetër, rezistenca ndaj insekteve në shënjestër mund të çojë në efekte negative të toksinave nga kulturat gjenetikisht të modifikuara në insekte të dobishme. ${ }^{70}$

Përhapja e polenit tek misrit Bt shkakton vdekjen e një insekti efektiv, vemje të fluturës monarkike. ${ }^{31}$ Përveç kësaj, janë prekur edhe insekte të tjera të dobishme të tilla si bushi i gjelbër (Chrysopa bead), i cili është i dobishëm për kontrollin e dëmtuesve të vetë misrit. ${ }^{59}$

Avantazhi i kultivimit të kulturave gjenetikisht të modifikuara konsiderohet se është reduktimi i konsumit të karburantit të traktorëve për kultivimin e tokës, reduktimin e erozionit të tokës dhe përmbajtjen e karbonit më të lartë në tokë. Mbajtja e karbonit në tokë rezulton në reduktimin e emetimeve të gazrave serrë. Dihet se rritja e niveleve atmosferike të gazrave serrë, siç është dyoksidi i karbonit, ka një ndikim negativ në mjedisin global. ${ }^{60}$ Cikli aktual i ndryshimeve klimatike mund të ketë një ndikim negativ në ekosistemin dhe rrjedhimisht të çojë në reduktimin e prodhimit të të lashtave. Prandaj, pranimi i kultivimit të kulturave bioteknologjike besohet se mund të ketë ndikim pozitiv në ekosistem. Ky konkludim padyshim se vjen në shprehje kur mbrohen sismtemet e bujqësisë moderne ose konvencionale. ${ }^{6}$ Për të parandaluar shqetësimet e ekosistemeve dhe biodiversitetit, është e nevojshme të kryhen vazhdimisht sprovat në terren. ${ }^{61}$

\subsubsection{Ndikimi i konsumit të UMGJ për shëndetin e njeriut}

Trupi i njeriut ka nevojë për ushqim që do të plotësojë nevojat e përditshme të energjisë dhe nevojave ushqyese për rritjen dhe zhvillimin e duhur ${ }^{13}$ Kërkesa për ushqim po rritet çdo ditë, por është e nevojshme të sigurohet një cilësi e përshtatshme dhe përmbajtje ushqyese gjatë prodhimit. Përveç problemit të kequshqyerjes në botë, problemi paraqet edhe vdekshmërinë dhe përhapjen e sëmundjeve të shkaktuara nga mungesa e mikronutrientëve si vitamina A, zinku, jodi dhe hekuri. Pjesa e ndjeshme e popullsisë, gratë shtatzëna dhe fëmijëve, ne mënyrë të veçantë janë prekur nga ky problem.

Bioteknologjia ofron një zgjidhje për shumë probleme të shkaktuara nga kequshqyerja. Përdorimi i ushqimeve përfituara nga kjo teknologji, përveç që kontribuon në përmirësimin dhe ruajtjen e shëndetit të njeriut, gjithashtu mund të tregojë efekte negative potenciale në shëndetin e njeriut, të tilla si toksiciteti, alergjia dhe rezistenca ndaj antibiotikëve. ${ }^{59}$ Duke pasur parasysh se kjo metodë e kultivimit të bimëve është relativisht e re në botë, është e vështirë të flitet për efektet afatgjata në shëndetin e njeriut. ${ }^{1}$ Për të ruajtur shëndetin, OBSH rekomandon që çdo ushqim të testohet individualisht për shkak se vlerësimet e përgjithshme nuk mund të bëhen mbi sigurinë e ushqimit OMGJ. Rrjedhimisht, është e rëndësishme të vlerësohet qëndrueshmëria e gjenit të ri, alergjeniciteti, për të përcaktuar përbërësin e ushqimit që ka një karakteristikë të mundshme ushqyese ose toksike, efektet e saj mbi cilësinë e ushqimit dhe efektet negative potenciale që mund të pasojnë pas modifikimit. ${ }^{62}$

\subsubsection{Efektet potenciale pozitive të UMGj në shëndetin e njeriut}


Megjithëse farat e bimëve MGJ janë më të shtrenjta, shpenzimet gjatë procesit të kultivimit janë dukshëm më të ulëta se kultivimi tradicional, gjë që do të ndikojë në çmimin e produktit përfundimtar, çka edhe duhet të na bëjë të mendojmë dy herë qëllimin e përgjithshëm. Modifikimi gjenetik i organizmave rezultoi në përfitime të mëdha ekonomike dhe përforcim të monopoleve.

\subsubsection{Biofortifikimi i mineraleve në UMGJ}

Kur vjen puna te mineralet në dietë, vëmendje e veçantë i kushtohet mungesës së hekurit dhe zinkut. Ndërsa përpiqet të zgjidhë këtë problem duke prodhuar shtesa të ndryshme ushqyese që përmbajnë përmbajtje minerale në rritje, kjo formë e vizionit shpesh është e padisponueshme për popullatën e varfër. Prandaj, si një strategji më e mirë për zgjidhjen e këtij problemi, është e preferueshme të rritet kultura transgjenike. Mungesën e tyre, bioteknologjia, po përpiqet ta zgjidhë me proceset e biofortifikimit, d.m.th. të rrisë biodisponibilitetin e këtyre elementëve në bimë si drithërat dhe bishtajoret. Strategjitë për rritjen e përmbajtjes së tyre bazohen në futjen e gjeneve që ushtrojnë shprehje të tepruar ose të reduktuar të përbërësve të caktuar.

Hekuri (Fe) është një mikronutrient thelbësor në të ushqyerit njerëzor dhe në ushqimin e kafshëve. Mungesa e këtij mikronutrienti në ushqime është kryesisht për shkak të disponueshmërisë së saj të reduktuar në tokë alkaline. Metodat e inxhinierisë gjenetike sigurojnë aftësinë për të futur gjene që kodojnë komponimet, të tilla si acid askorbik, roli i të cilit është rritja e thithjes së hekurit dhe elementëve të tjerë në gjurmë. Duke përdorur këto metoda, thithja e hekurit rritet, madje edhe në prani të inhibitorëve natyrorë. ${ }^{63,64,65}$

Përveç hekurit, një mineral shumë i rëndësishëm për shëndetin e njeriut është zinku (Zn), i cili është thelbësor për veprimtarinë e një numri të madh të enzimeve në trupin e njeriut. Mungesa e zinkut mund të shkaktojë pasoja negative në zhvillimin fizik, riprodhues dhe neurologjik. Prandaj, për shëndetin e njeriut, është me rëndësi të madhe që biofortifikimi i kulturave për të rritur përmbajtjen e këtij minerali. ${ }^{66}$ Konsiderohet të jetë një nga arsyet kryesore për deficitin e zinkut në ushqimin e bazuar në grurë. Gruri është një kulture që tregon përmbajtje të ulët të zinkut, dhe miellin e grurit dhe kultivimi i tij në tokë me mungesë zingu ndikojnë gjithashtu në përmbajtjen e ulët të këtij minerali. Prandaj, modifikimi gjenetik i gjenomit të grurit në masë të madhe mund të zgjidhë problemin e kësaj pamjaftueshmërie. ${ }^{67}$

Një kulturë tjetër, që synon arritjen e përmbajtjes së lartë të elementëve në gjurmë, është Sorgumi (Sorghum bicolor). Metodat e modifikimit gjenetik rrisin përmbajtjen e zinkut dhe pastaj përmbajtjen e hekurit. Kjo është arsyeja pse popullsia në Afrikën Sub-Sahariane, ku kjo bimë përdoret në sasi të mëdha në të ushqyerit, siguroi ushqime të pasuruara me minerale të rëndësishme. ${ }^{68}$

\subsubsection{Biofortifikimi i vitaminave në UMGJ}

Azia Juglindore dhe Afrika janë veçanërisht të prekur nga kequshqyerja dhe kjo është për shkak se dieta bazohet kryesisht në oriz ose drithëra të tjerë me përmbajtje të ulët të mikronutrientëve, 
veçanërisht vitaminave. Gjithashtu, ka një rritje në numrin e fëmijëve me çrregullime të funksionit vizual, me kequshqyerje të dukshme. Arsyeja më e shpeshtë e kequshqyerjes dhe verbërisë në fëmijët është mungesa e vitaminës $A(V A D)$ në dietë. ${ }^{59}$ Organizmi njerëzor mund të sintetizojë vitaminën A nga prekursori i tij $\beta$-caroten, i quajtur edhe pro-vitaminë A. $\beta$ karotinë gjendet me shumicën bimë, por është në deficit në drithërat e grurit. Duke qenë se orizi është drithi kryesor në vendet ku VAD është gjerësisht e pranishme, ai i është nënshtruar metodave të inxhinierisë gjenetike për të kryer biofortifikimin e $\beta$-karotenit në grurë. ${ }^{17}$

Në këtë mënyrë, dizajnohet orizi i artë, i cili në endospermën e grurit ka rritur $\beta$-karoten ose pro-vitaminë A. Si rezultat, metodat e inxhinierisë gjenetike janë gjetur për të ofruar një zgjidhje adekuate në luftën kundër VAD. produkti më i famshëm i biofortifikimit dhe i është nënshtruar këtij procesi disa herë. Në rastin e parë ishte orizi MGJ që shpreh sintezën e gjinisë phyton (Psy) narcis (Narcissus Poeticus), së bashku me gjenet e bakteriale të fitonit desaturazë (CrtI). Rezultatet ishin të kënaqshme në drejtim të rritjes së biodisponueshmëria e karotenoidëve. Megjithatë, rasti i dytë i orizit të artë me Psy dhe Crtl gjenom i misrit dhanë në mënyrë të konsiderueshme biodisponueshmërin e $\beta$-karotenit se sa rasti i parë. ${ }^{69}$

Për të rritur përmbajtjen $\beta$-arotenit, përveç orizit, metodat e inxhinierisë gjenetike aplikohen edhe në bimë të tjera. Një shembull është mustardi, e cila synon kryesisht të ofrojë një zgjidhje për luftën e mungesës së vitaminës A - Vitamin A deficiency (VAD) në Indi, ku popullsia konsumon sasi të mëdha të vajit nga mustardi. Studimet kanë treguar se përveç rritjes së përmbajtjes $\beta$-karotenit, kostot do të reduktohen dhe vetëm disa pika të vajit të kësaj bime do të ishin të mjaftueshme për të plotësuar nevojën e përditshme për vitaminë A. ${ }^{70}$

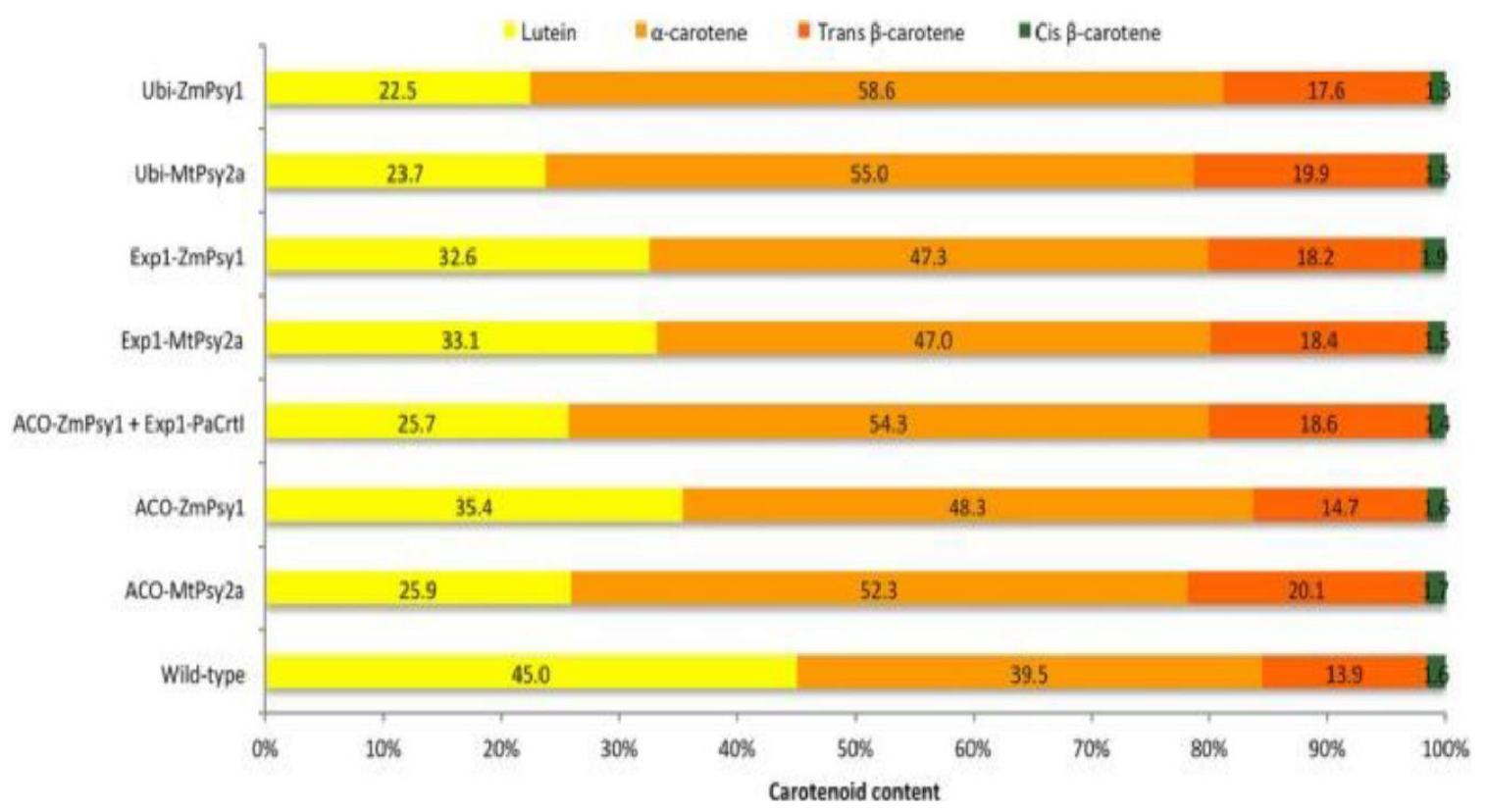


Figura 5. Përqindja e karotenoidit të mbajtur në frytet e varieteteve të egra dhe transgenike të bananeve. ${ }^{69}$

Një tjetër mikronutrient i rëndësishëm në të ushqyerit njerëzve është Vitamina E, roli kryesor i të cilit në trup është ulja e nivelit të kolesterolit në gjak, parandalimi i përhapjes së qelizave të kancerit të gjirit dhe vetitë antioksiduese. Mungesa e saj mund të çojë në një rritje të rrezikut të sëmundjeve kardiovaskulare, anemi për shkak të dëmtimit oksidativ të eritrociteve, retinopatisë dhe rënies së përgjigjes imune. Për qëllim të arritjes së një përmbajtjeje të lartë të vitaminës E në dietë, modifikimet gjenetike bënë biofortifikimin e misrit dhe manioke. Në këtë mënyrë ushqimi furnizohet për të plotësuar nevojat e përditshme të vitaminës $E$, veçanërisht në vendet ku burimi kryesor i ushqimit është ushqimi i dobët me këtë nutrient. ${ }^{59}$

\subsubsection{Efektet potenciale negative të UMGJ mbi shëndetin e njerëzve}

Shqetësimet për përdorimin e ushqimeve të OMGJ-së bazohen në dyshimet se modifikimi gjenetik do të rezultojë në ndërveprime të padëshiruara të gjeneve, transmetim horizontal gjenetik, dhe do të shkaktonte rezistencë antibiotike, alergjenicitet të mundshëm dhe toksicitet. 31

\subsubsection{Alergjeniciteti potencial i UMGJ}

Një nga efektet negative të konsumimit të UMGJ, i cili është një shqetësim i madh për konsumatorët, është reaksione alergjike. Ekspozimi i përsëritur ndaj alergjeneve mund të rezultojë në goditje anafilaktike dhe të shkaktojë vdekjen. Për shkak të rrezikut të lartë të efekteve të dëmshme në shëndetin e njeriut, konsumatorët janë të shqetësuar nëse bimët e reja gjenetike do të rrisin numrin e reaksioneve alergjike. ${ }^{70}$

Alergjeniciteti i OMGJ-ve mund të zhvillohet për shkak të transferimit të gjeneve, i cili kodon një nga alergjenët ose proteina shumë të ngjashme me alergjenët midis dy organizmave të ndryshëm. ${ }^{71}$ Para modifikimit, është e rëndësishme të dihet nëse gjen është me natyrë alergjike. Është gjithashtu e rëndësishme të përcaktohet nëse sekuenca aminoacide e proteinës, shprehja e së cilës duhet të gjendet, ka një strukturë të ngjashme me proteinën alergjenike. ${ }^{70} \mathrm{~A}$ do të bëhet proteina e shprehur në organizmin tjetër një alergjen që vlerësohet në bazë të rezistencës së tij ndaj pepsinës në traktintretës. ${ }^{71,72}$

Para se të vendosni OMGJ-të në treg, duhet të bëhet një vlerësim i rrezikut të efekteve anësore. Ndër të tjera, kjo është ekspozimi ndaj alergjeneve në individë të ndjeshme mund të shkaktojë një reaksion alergjik. ${ }^{59}$ ushqime OMGJ mund të shkaktojnë reaksione alergjike për shkak të pranisë së proteinave të reja, ose ndërveprimin e një proteine re me endogjen. ${ }^{31}$ Vlerësimi i alergjicitetit të bimëve të caktuara MGJ përbëhet nga vlerësimet e të gjithë bimëve dhe vlerësimi i proteinave të reja të shprehura. Kur është fjala për vlerësimin e alergjive të tërë bimore MGJ është testuar nëse modifikimi gjenetik të ketë një efekt potencialisht negativ në nivelin e alergjeneve që janë të natyrshme të pranishme nëbimë. Deri më tani, numri njohur i ushqimeve, të tilla si soje, gruri, qumësht, arra, kikirikë, butak, peshk dhe vezë, të cilat janë gjetur të shkaktojë një reaksion alergjik. Prandaj, është shumë e rëndësishme të dimë nëse 
përdoret një gjen nga një burim potencialisht alergjik. Burimet e gjeneve, të tilla si bakteret, misër dhe oriz tregojnë më pak gjasa për të koduar proteinat që mund të shkaktojnë reaksionesensiviteti. Me ndihmën e metodave biofortifikuese, zbulon ngjashmëri të sekuencave aminocidike proteinike e cila futet, në lidhje me sekuencat e alergjenëve të njohura të ushqyerin e njeriut. ${ }^{70}$

Një shembull i një rasti kur kultivimi MGJ nuk është vazhduar për shkak të alergjisë së dyshuar është bimë MGJ bizele. Ky modifikim synonte rritjen e përmbajtjes së aminoacideve të cisteinëve dhe metioninëve, por proteina e re e shprehur tregoi një rrezik të lartë të alergjenicitetit. Duke zbuluar metoda për vlerësimin e përbërjes dhe sasisë së OMGJ-ve në ushqim, mund të jetë e mundur të përcaktohet qëndrueshmëria e rrezikut të alergjisë ushqimore para se të vendoset në treg. Deri më sot vetëm një rast është konstatur se ushqime të caktuara MGJ janë ndaluar të tregtohen për shkak të alergjisë. Bëhet fjalë për sojën MGJ në të cilën është futur një gjen i arrës braziliane (Bertholetiae excelsa), i cili është ka shkaktuar një reaksion alergjik. ${ }^{70}$

Testet e kryera kanë treguar se ka të ngjarë që ushqimet OMGJ të shkaktojnë reaksion alergjik ndaj konsumatorëve, si dhe në format tradicionale të prodhimit të ushqimeve. Me fjalë të tjera, njerëzit që janë alergjikë ndaj çfarëdo lloj ushqimi ose përbërësi ushqimor duhet të shmangin të njëjtin ushqim pavarësisht nëse është MGJO apo jo. ${ }^{73} \mathrm{Në} \mathrm{vitet} \mathrm{e} \mathrm{fundit} \mathrm{janë} \mathrm{bërë} \mathrm{përpjekje}$ intensive për të përmirësuar modelin e kafshëve, organizmat e të cilëve do të imitojnë mekanizmin dhe fazat reagimet e mbindjeshmërisë, të cilat do të lejojnë një vlerësim më të mirë të rrezikut para komercializimit të OMGJ. ${ }^{74}$

\subsubsection{Potencial kancerogjenik i UMGJ}

Studimet shkencore kanë treguar se pasoja, një nga efektet negative të konsumimit të ushqimeve UMGJ, mund të jetë formimi i tumoreve në rritje të gjëndrës laktike. Ky zbulim ka krijuar shqetësim në rrethin e shkencëtarëve që kundërshtojnë konsumimin e këtyre ushqimeve, pasi kjo do të thotë zbulimin e gabimit më të madh të teknologjisë së re. Përveç shqetësimeve ekzistuese të popullsisë botërore për UMGJ, dyshimi i këtij supozimi e rëndon më tej situatën.

Për të provuar këtë hipotezë, u krye një eksperiment në të cilin disa grupe të minjve të ushqyer me UMGJ, ndërsa të tjerat ushqeheshin me ushqime të kultivuara në mënyrë tradicionale. Në minjtë që ushqehen me UMGJ, ka ardhur deri tek zhvillimi i tumoreve në gjëndrën e qumështit, por edhe dëmtimin e funksionit të mëlçisë dhe veshkave. 


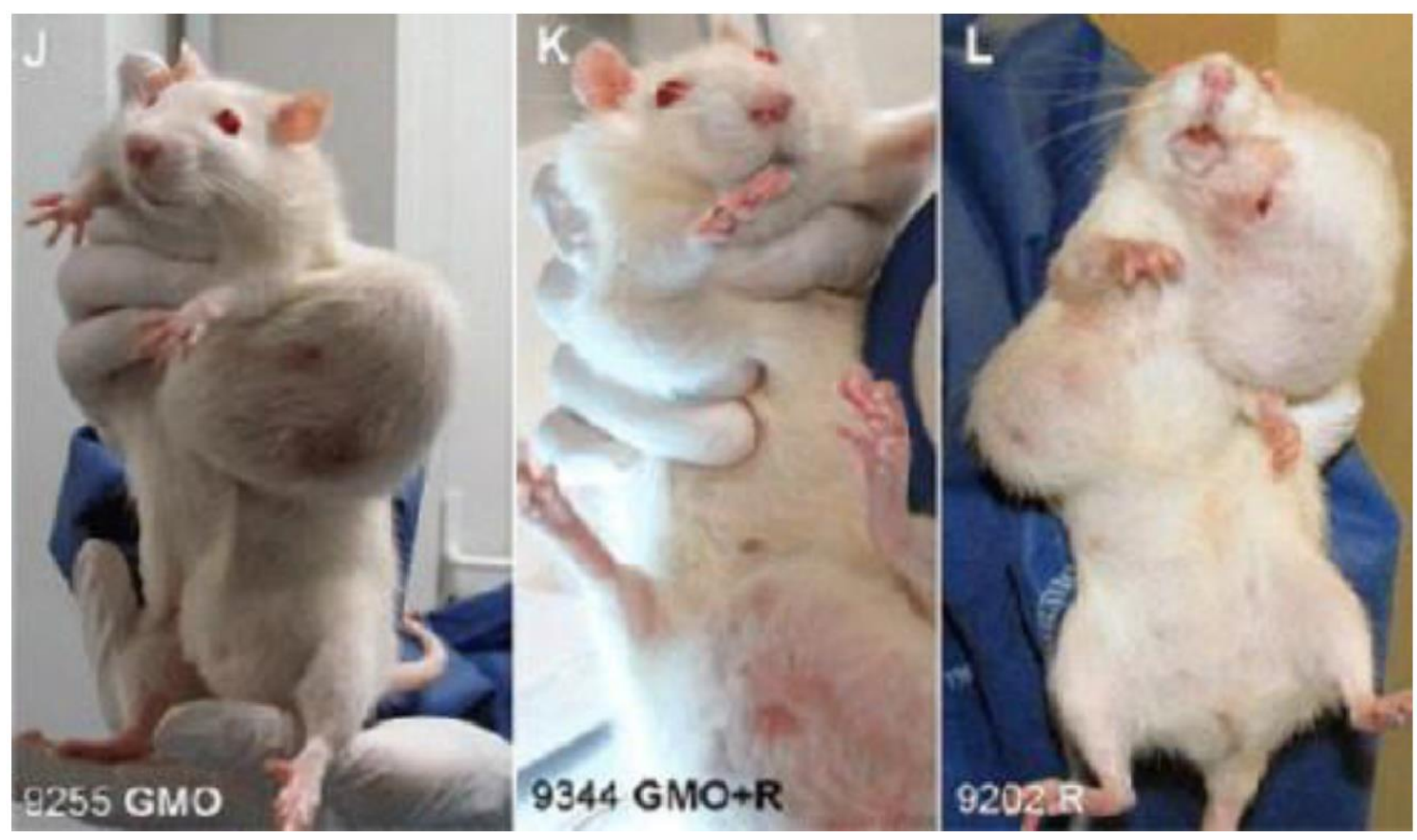

Foto 2. Tumor i gjëndrës së qumështit tek minjtë

Kjo ka shkaktuar pasiguri në mesin e shkencëtarëve, gjë që është arsyeja për kryerjen e një eksperimenti të ri në të cilin minjtë ushqehen me tre lloje të ndryshme të misrit MGJ, të disponueshme në treg për ushqim njerëzor dhe të kafshëve. Rezultati tregoi toksicitet potencial hepatorenal kur konsumojnë këto lloje të misrit. Pas kësaj, disa vende kanë ndaluar importin e misrit MGJ. ${ }^{75}$

\subsubsection{Toksiciteti potencial i UMGJ}

Shqetësimi për ushqimin e OMGJ po rritet kur efektet sekondare dhe pleiotropike merren parasysh në trup. Me fjalë të tjera, gjen i sapo futur mund, në një masë më të vogël apo më të madhe, të kontrollojë procese të shumëfishta në të njëjtën kohë. Për shembull, ajo mund të kodojë enzimat në reaksione biokimike dhe të rezultojë në përqendrime më të larta toksine. Problemi i toksicitetit të mundshëm të UMGJ është më i madh kur substanca toksike shprehet në pjesën ushqimore të bimës, e cila mund të rezultojë në efekte të padëshirueshme në shëndetin e njeriut. ${ }^{1}$ Bimët MGJ të prodhuara për të qenë rezistent ndaj dëmtuesve të ndryshëm, shprehin proteinat e kristaleve të insekticideve (Cry) që rrjedhin nga bakteret Bacillus thuringiensis. Proteina Cry është modifikuar për të arritur një spektër të gjerë të aktivitetit insekticid në bazë të ndryshimeve në sekuencat e aminoacideve. ${ }^{76}$

Disa studime kanë treguar se është mundësi e vogël që të ndryshojnë sekuencat e aminoacideve, që të rezultojnë në formimin e një proteine toksike. Nëse proteina e modifikuar e ruan funksionin e saj biologjik, ngjashëm me proteina të ngjashme që kanë një histori të përdorimit të sigurisë (HOSU), mund të thuhet se një proteinë e tillë është e sigurt për t'u përdorur. Megjithatë, individët pretendojnë se proteinat e modifikuara mund të jenë toksike për njerëzit që konsumojnë ushqime OMGJ. Prandaj, për organizmat MGJ që mbajnë 
rezistencë ndaj insekticideve, testimi i toksicitetit kronik mbi kafshët duhet të kryhet para komercializimit. ${ }^{77}$ Shkencëtarët kanë kryer disa studime eksperimentale mbi toksicitetin e mundshëm të UMGJ për disa lloje të kafshëve të ushqyer me UMGJ për një periudhë të caktuar kohore.

Tabela 2. Përmbledhje e studimeve eksperimentale të toksicitetit të ushqimeve OMGJ ndaj llojeve të ndryshme të kafshëve ${ }^{62}$

\begin{tabular}{|c|c|c|c|}
\hline Bima & Lloji i kafshës & $\begin{array}{l}\text { Periudha } \\
\text { ushqimit }\end{array}$ & Efektet e dëmshme \\
\hline Patatja Bt & Minjtë & muaj & $\begin{array}{l}\text { Ndryshim i vogël i strukturës së } \\
\text { ileumit }\end{array}$ \\
\hline Patatja Bt & $\begin{array}{l}\text { Minjtë (mijë të } \\
\text { mëdhenj) }\end{array}$ & 0 ditë & Proliferimi i mukzës së stomakut \\
\hline Misri Bt & Pula & 8 ditë & Pa efekte të dëmshme \\
\hline Misri Bt & Derra & 1 ditë & Pa efekte të dëmshme \\
\hline Soja Ht & Pula & 1 javë & Pa ndryshime të dukshme \\
\hline Soja Ht & $\begin{array}{l}\text { Minjë dhe (mijë } \\
\text { të mëdhej) }\end{array}$ & 5 javë & $\begin{array}{l}\text { Pa aktivitete imunotoksike dhe } \\
\text { efekte anësore }\end{array}$ \\
\hline Oriz MGJ & $\begin{array}{l}\text { Minjtë (mijë të } \\
\text { mëdhej) }\end{array}$ & 0 ditë & $\begin{array}{lll}\begin{array}{l}\text { Ndryshime } \\
\text { histopatologjike }\end{array} & \text { të } & \text { lehta } \\
\end{array}$ \\
\hline Oriz MGJ & $\begin{array}{l}\text { Minjtë (mijë të } \\
\text { mëdhenj) }\end{array}$ & 0 ditë & Ndryshime hematologjike \\
\hline
\end{tabular}

Pas këtyre studimeve, vite më vonë, u kryen teste të reja në minj, Bt oriz dhe Bt misri, të cilat treguan hematotoksicitet pas intubacionit të proteinës Cry të stomakut. Disa shkencëtarë besojnë se shfaqja e hematotoksicitetit është në fakt rezultat i kushteve të pamjaftueshme të kontrolluara gjatë eksperimentit, pas ekspozimit të përsëritur nuk është provuar. Studime të tjera kanë treguar se nëse proteinat e Cry janë futur në minj, rektalisht ose nazalisht, ata nxisin përgjigjen imune të organizmit. Është e rëndësishme të theksohet se doza e proteinave Cry që kanë shkaktuar një përgjigje imune në minj janë rreth një mijë herë më e lartë se ekspozimi i mundshëm i njerëzve kur konsumojnë ushqime Bt. Gjithashtu, metodat e aplikimit të ushqimeve Bt tek minjtë eksperimental janë të ndryshme në lidhje me mënyrën në të cilën këto ushqime aplikohen nga njerëzit. Përveç kësaj, asnjë model kafshësh nuk mund të konsiderohet relativ për parashikimin e përgjigjes imune në organizmin e njeriut. ${ }^{77}$

\subsubsection{Rezistenca ndaj antibiotikëve}

Bimët MGJ zakonisht përmbajnë gjenet SMGs, rezistente ndaj antibiotikëve, duke shkaktuar shqetësim të madh për publikun. ${ }^{78}$ Në procesin e transferimit të gjeneve dhe formimin e një gjenomi të ri në një organizëm të veçantë, përdoren markerë SMG ose gjene që kodifikojnë rezistencën ndaj antibiotikëve në baktere. Bartja horizontale e gjenit (HGT) përfshin transferimin e materialit gjenetik në një organizëm të llojeve të njëjta ose të ndryshme dhe ndodh si një dukuri natyrore midis baktereve. Për shkak të transformimit të baktereve në zinxhirin ushqimor, HGT mund të rezultojë në transmetimin e gjeneve rezistente ndaj 
antibiotikëve nga bima MGJ në traktin gastrointestinal të njerëzve. Ky fenomen rrjedhimisht shkakton një rënie të rezistencës ndaj antibiotikëve dhe një efekt të reduktuar ndaj tyre. ${ }^{31}$

Publiku i përgjithshëm kishte frikë nga rritja e numrit të baktereve që kishin zhvilluar rezistencë ndaj antibiotikëve përmes bakterit Staphylococcus aureus (MRSA) rezistent ndaj meticillinës. Ulja e rezistencës së antibiotikëve mund të rezultojë në rreziqe të rëndësishme të shëndetit të njeriut. Si një zgjidhje e mundshme për problemin e mbajtjes së markerëve të SMG në bimë, shkencëtarët thonë se markerët e njëjtë duhet të hiqen pas transferimit. Përveç kësaj, ajo ka të bëjë me zhvillimin e metodave të reja të inxhinierisë gjenetike që nuk do të përfshijnë përdorimin e këtyre markerëve kur kryejnë transferimin e gjeneve nga një organizëm në tjetrin.

\subsection{Etiketimi i UMGJ}

Ka pasur një mosmarrëveshje midis fermerëve dhe konsumatorëve në botë për vite në lidhje me prodhimin dhe përdorimin e OMGJ-ve. Fermerët evokojnë përfitimet e këtyre ushqimeve si rendimenti më i lartë, zvogëlimi i urisë në botë dhe prodhimi i cilësisë më të lartë dhe ushqimit të shijshëm. Nga ana tjetër, konsumatorët përqendrohen më shumë në disavantazhet e zhvillimit të këtyre metodave të prodhimit të ushqimit, duke pasur frikë se kulturat e reja do të kenë ndikime të pafavorshme në shëndetin, mjedisin dhe biodiversitetin. ${ }^{54}$

Rritja e prodhimit, shitjes dhe përdorimi i ushqimeve OMGJ ka shkaktuar pasiguri në botë, sidomos kur është fjala për pasojat e përdorimit të tyre në shëndetin e njeriut. Fakti është se ka prova shkencore që ushqimet e OMGJ-ve janë të sigurt për t'u përdorur dhe qëndrimi i OBSHsë është se ushqimi i tillë nuk do të ketë ndikim negativ në shëndetin. Megjithatë, konsumatorët kërkojnë etiketimin e detyrueshëm të produkteve që përmbajnë ose vijnë nga organizmat e modifikuar gjenetikisht, mbi këtë bazë ata vetë do të vendosin nëse do të konsumojnë apo jo produkte të tilla.

Anëtarët e agrobizneseve të mëdha kundërshtojnë etiketimin e pranisë së OMGJ-ve në produkte dhe po përpiqen të tregojnë se UMGJ janë po aq të sigurta sa ato të fituara nga kultivimi tradicional. Disa shkencëtarë pohojnë se etiketimi mund të çojë në huri mes konsumatorëve. Ndryshe nga SHBA ku shkencëtarët dhe organizatat janë kryesisht kundër etiketimit, situata në Bashkimin Evropian është e ndryshme. Komisioni Evropian mbron pozicionin e konsumatorit për etiketimin e detyrueshëm të produkteve të tilla, nëse ato përmbajnë ose në ndonjë mënyrë kanë origjinën nga OMGJ-të. ${ }^{79}$

Për të siguruar një zgjidhje për konsumatorët, në Bashkimin Evropian është krijuar një sistem që përfshin parime parandaluese që bazohen në kërkesat për etiketimin e UMGJ. Në këtë mënyrë, konsumatorët kanë lirinë e zgjedhjes. Përkundrazi, Shtetet e Bashkuara kundërshtojnë pretendimet se ky ushqim duhet të etiketohet siç duhet, pasi që këto procedura do të çonin në kosto më të larta të panevojshme. Megjithatë, ato i referohen konceptit të ekuivalencës, d.m.th. nëse UMGJ sipas përbërjes dhe cilësisë nuk ndryshojnë nga ushqimet ekuivalente të fituara nga kultivimi tradicional, ato nuk duhet të etiketohen. Nëse UMGJ tregojnë një përmbajtje të ndryshme ushqyese ose alergji, FDA kërkon etiketimin e detyrueshëm. Ndryshe nga Bashkimi Evropian, Shtetet e Bashkuara janë shumë më fleksibël sa i përket ligjit për UMGJ-ke. ${ }^{54}$ 
Rregulloret ndërkombëtare tregojnë etiketimin e detyrueshëm të OMGJ-ve të pranishme në ushqim nëse përmbajtja e tyre është më e lartë se kufiri i rekomanduar.

\subsubsection{Rregullativat ligjore $B E / R K S$}

Sa i përket Ligjit të Ushqimit në RKS, nëse e lexojmë disa herë nuk mund të gjejmë as citat që kërkon deklarimin apo etiketimin e UMGJ-ve apo OMGJ-ve. Neni 19 i kreut V për Ushqimin e ri dhe OMGJ shpjegon më tej:

1. Në ushqim të ri bëjnë pjesë këto kategori të ushqimit:

1.1.ushqimi dhe përbërësit e ushqimit të cilët përmbajnë organizma gjenetikisht të modifikuar ose përbëhet nga ata;

1.2. ushqimi ose përbërësit e ushqimit, përveç aditivëve -aromave dhe enzimave, të cilët janë prodhuar nga OMGJ, por nuk përmbajnë OMGJ;

1.3.ushqimi ose përbërësit e ushqimit me strukturë të re primare ose me strukturë të re molekulare të modifikuar qëllimisht;

1.4.ushqimi ose përbërësit e ushqimit të cilët përbëhen nga mikroorganizmat, kërpurdhat, algët ose janë të izoluara nga ato;

1.5.ushqimi ose përbërësit e ushqimit të cilët përbëhen nga bimët, shtazët, materiet minerale dhe sintetike ose janë të tajitur nga ato, përveç ushqimit dhe përbërësve të ushqimit të cilët janë përfituar në mënyrën tradicionale të shumimit ose për të cilët dihet më herët se mund të konsumohen;

1.6.ushqimi dhe përbërësit e ushqimit në të cilët është zbatuar procedura e prodhimit e cila tani nuk shfrytëzohet, ndërsa në rastet kur ajo shkakton ndryshime të dukshme në përbërjen dhe strukturën e ushqimit, në përbërësit e ushqimit, të cilët ndikojnë në vlerën e tyre ushqyese, metabolizëm apo në shkallën e materieve të padëshiruara.

2. Kategoritë e ushqimit të ri sipas paragrafit 1 të këtij neni nuk duhet:

2.1.të jenë të rrezikshme për shëndetin e konsumatorit të fundit;

2.2.të shkaktojnë huti te konsumatori;

3. Ministria e Shëndetësisë, në bashkëpunim me Ministrinë e Bujqësisë, me akte nënligjore i përcaktojnë rregullat për prodhimin, procesimin dhe distribuimin e ushqimit të ri dhe ushqimit nga organizma të modifikuar gjenetikisht.

4. Ministria e Bujqësisë, nxjerr akte nënligjore për prodhimin, procesimin dhe distribuimin e ushqimit tradicional dhe gjeografikisht të mbrojtur.

KREU VI mbi deklarimin e ushqimit nga Neni 20 shpjegon më tej se: 
1. Ushqimi i cili është plasuar në tregun e Kosovës duhet ta ketë deklaratën.

2. Deklarata nënkupton të gjitha shenjat e shkruara, emërtimin tregtar, shenjën mbrojtëse, emërtimin e markës, paraqitjen e fotografive ose simbolin i cili i referohet ushqimit dhe vendoset në ambalazh, etiketën ngjitëse ose të varur dhe informatat të cilat e përcjellin ose i referohen atij ushqimi.

3. Deklarata duhet të jetë e shkruar në mënyrë të dukshme, si dhe duhet të jetë e lexueshme dhe e kuptueshme.

4. Deklarata duhet të përmbajë këto shënime:

4.1. emërtimin me të cilin ushqimi shitet;

4.2. listën mbi përshkrimin e përbërësve;

4.3. sasinë dhe kategorinë e përbërësve të caktuar;

4.4. sasinë neto për ushqimin e paketuar;

4.5. afatin e përdorimit;

4.6. kushtet e ruajtjes, kur ato munden të ndikojnë në skadencën e ushqimit;

4.7.emrin dhe adresën e prodhuesit ose emrin dhe adresën e atij që e paketon ose e plason në treg,

5. Për produktet e importuara, krahas emrit dhe adresës së prodhuesit duhet të jetë i shënuar edhe emri, adresa e selisë së importuesit dhe shteti i origjinës.

\section{DEKLARIMI I PROBLEMIT}

\section{METODOLOGJIA}

Në këtë studim janë analizuar 4 mostra nga prodhues të ndryshëm vendorë dhe të importit. Mostrat janë analizuar me metodën kuantitaiva AGRASTRIP. metodë e cila përcakton nëse ushqimi është i modifikuar gjenetikisht ose jo. Në këtë studim janë analizuar disa mostra nga dy prodhues të ndryshëm që janë të pranishëm në tregun e Kosovës dhe të cilat janë produkte vendore dhe të importuara, metoda e analizës është Agrastrip ${ }^{\circledR}$ MGJO - Romer labs®. Mostrat janë marrë në mënyrë të rastësishme në treg dhe fokusi i studimit ishte misri (vendor dhe i importuar).

\section{Procedura e punës}

$\checkmark$ Fillimisht përgatitet mostra duke e luajtur 


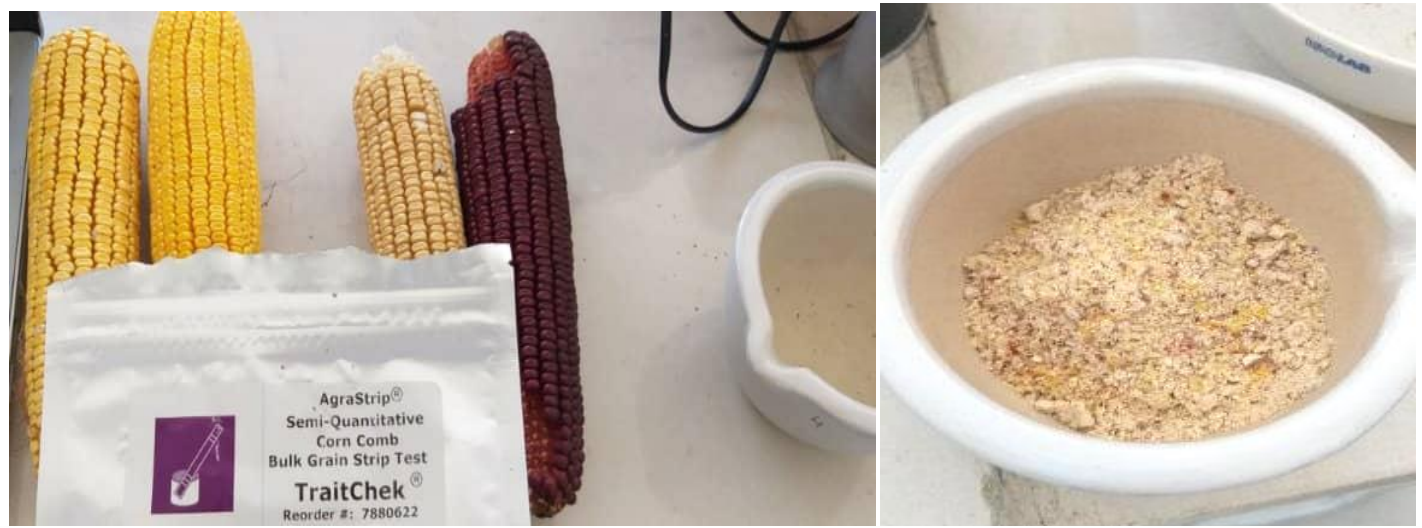

Foto 3. Bluarja e mostrës

$\checkmark$ Përgatitet mostra në raport 1:2 (50 g mostër $100 \mathrm{ml}$ bufer)

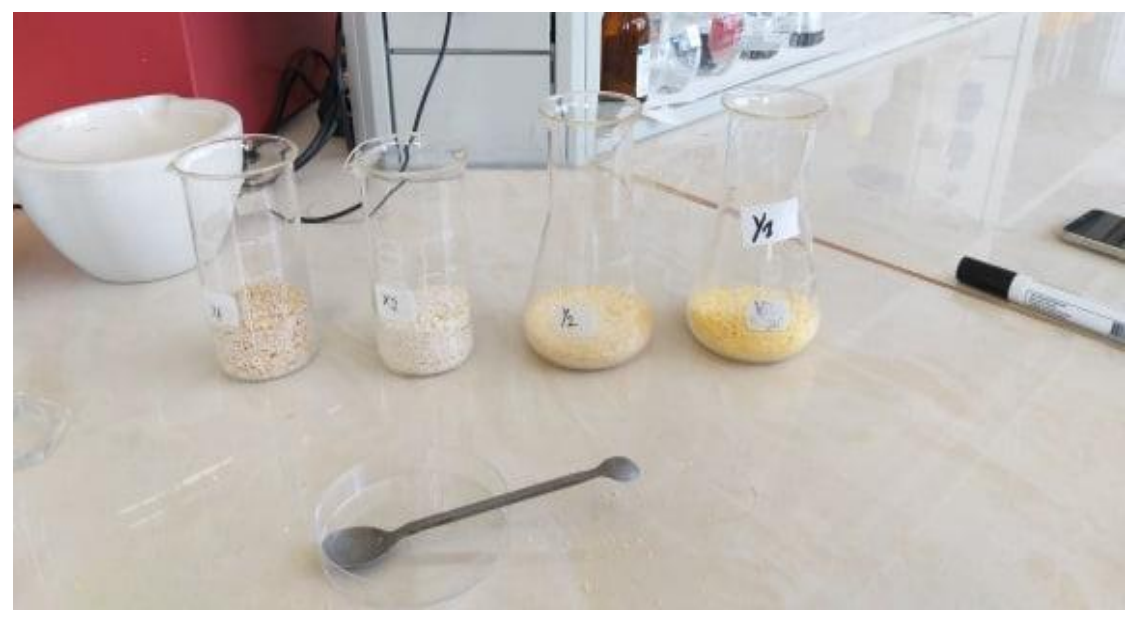

Foto 4. Mostra e përgatitur 
$\checkmark$ Merren nga $10 \mathrm{ml}$ nga mostra e përgatitur dhe transferohen në një gotë laboratorike, dhe kitet e agrastrip MGJo test vendosen në mostrat, lihen të qëndrojnë afërsisht 5 minuta.

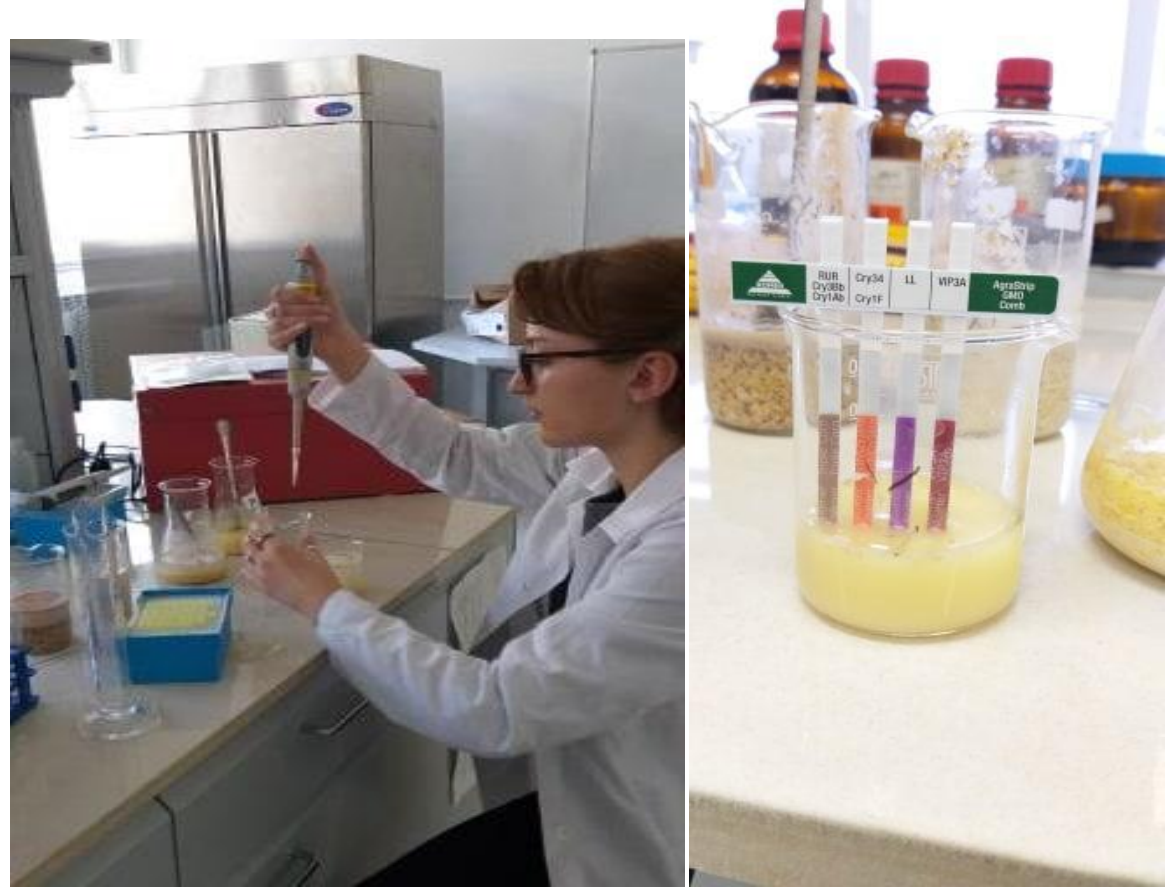

Foto 5. Vendosja e Kitit në mostër

$\checkmark$ Mbas 5 minutave, largohen kitet, dhe lexohen në mënyrë vizuale.

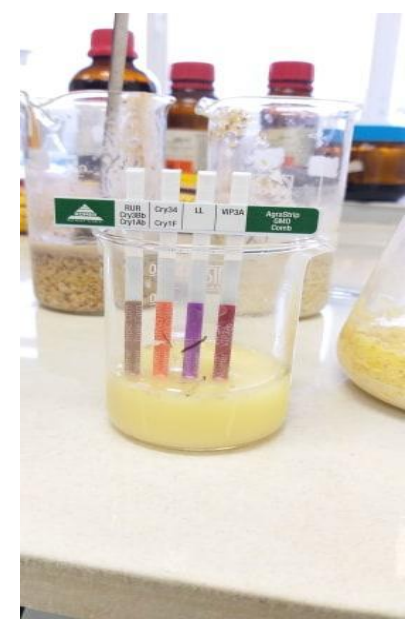

Foto 6. Leximi i rezultateve

$\checkmark \quad$ Një vijë e vetme vjollce në pjesën qendrore të testit = rezultat negativ.

$\checkmark$ Dy vija ngjyrë vjollce në zonën e rezultatit = rezultat pozitiv .

$\checkmark$ Asnjë linjë kontrolli nuk shfaqet = rezultati i pavlefshëm. 


\section{PREZANTIMI DHE ANALIZA E REZULTATEVE}

Në këtë studim janë analizuar 8 mostra nga prodhues të ndryshëm (vendor dhe të importit), kultivarët e të cilëve përbëjnë një përqindje të madhe në të ushqyerit bazë në RKS, sidomos në vendet rurale dhe veçanërisht kjo lëndë e parë me origjinë bimore, misri, përbën ushqimin kryesor nëpër ferma brenda RKS. Mostrat janë marrë në baza të rëndomta konceptualisht nga produkti i misrit dhe nga vet misri. Gjithsej janë analizuar tetë mostra. Katër prej tyre kanë qenë kultivar shqiptar të misrit dhe prodhime vendore rrjedhimisht, kurse dy të tjerat të kryqëzuara dhe të importuara. Misri i mostrave të tilla përdoret përpos për ushqim të njerëzve edhe të kafshëve. Kjo përbën rëndësi të madhe, pasi që misri është lëndë e parë me origjinë bimore si përbërës për shumë ushqime dhe ushqim të kafshëve që i konsumojmë direkt.

Mostrat e analizuara janë pasqyruar në tabelën e mëposhtme, ku me $\mathrm{X}$ janë shënuar mostrat e importit dhe me Y janë shënuar mostrat e vendore. Duhet theksuar se mostrat e importit ishin të deklaruara si të kryqëzuara jo të modifikuara.

Tabela 3. Rezultatet e testimit të mostrave të misrit vendor dhe atij të importit

\begin{tabular}{|l|l|l|}
\hline Lloji i mostrës & Mostra & Rezultati \\
\hline Improti & $\mathrm{X}_{1}$ & Negativ \\
\hline Improti & $\mathrm{X}_{2}$ & Negativ \\
\hline Improti & $\mathrm{X}_{3}$ & Negativ \\
\hline Improti & $\mathrm{X}_{4}$ & Negativ \\
\hline Vendore & $\mathrm{Y}_{1}$ & Negativ \\
\hline Vendore & $\mathrm{Y}_{2}$ & Negativ \\
\hline Vendore & $\mathrm{Y}_{3}$ & Negativ \\
\hline Vendore & $\mathrm{Y}_{4}$ & Negativ \\
\hline
\end{tabular}

Rezultate e fituara tregojnë se të gjitha mostrat e analizuara nuk paraqesin ndryshime në aspektin e modifikimit gjenetik. 


\section{KONKLUZIONE DHE REKOMANDIME}

Duke ju referuar rezultateve të fituara nga ky studim mund të arrijmë në përfundim dhe të rekomandojmë:

$\checkmark$ Të gjitha mostrat e testuara për modifikim nuk kanë treguar rezultate pozitive.

$\checkmark$ Kjo temë është një fillim i studimit në këtë fushë dhe mundësi e kufizuar për të pasur një studim të thelluar, por nuk do të thotë që në treg nuk ekzistojnë ushqime të modifikuara.

$\checkmark$ Edhe pse ekziston një rregullore për organizmat e modifikuara gjenetikisht ajo nuk është ende në zbatim.

$\checkmark$ UMGJ dhe OMGJ duhet të deklarohen për të mbrojtur të drejtat e konsumatorit.

$\checkmark$ Fushatë sensibilizuese nga institucione shtetërore dhe arsimore për të njohur ushqimet e modifikuara gjenetikisht, të dinë anët negative dhe pozitive të këtyre produkteve.

$\checkmark$ Mos deklarimi i këtyre produkteve dhe mos njohja e tyre po na çon në uljen e prodhimeve tradicionale dhe organike sepse po shiten me të njëjtin çmim në treg.

$\checkmark$ Konsumatori duhet të zgjedh për ushqimin e jo t'i imponohet pa u deklaruar.

Duke u bazuar në dhënat e këtij studimi dhe të dhënat e autorëve të ndryshëm për këtë problematik rekomandojmë.

$\checkmark$ Studime më të thelluara në RKS për pranin e OMGJ rrjedhimisht dhe të UMGJ.

$\checkmark$ Mbi bazën e të dhënave që do të fitohen nga studime e pikës paraprake të Hapet një debati më i gjerë për këtë çështje ku do të përfshihen specialistë të fushave që i përfshinë kjo problematik dhe të gjitha grupet e interesit.

$\checkmark$ Zbatimi i rregullores dhe aplikimi i monitorimit të vazhdueshëm për OMGJ/UMGJ.

$\checkmark$ Mbrojtja e prodhimeve tradicionale duke i përcaktuar qartë kush janë ushqimet e modifikuara dhe kush janë prodhimet organike. 


\section{LITERATURA}

(1) Bawa AS, Anilakumar KR. Genetically modified foods: safety, risk and public concerns - a review. Journal of Food Science and Technology [Internet]. 2013;50(6):1035-1046. Mund të gjendet: https://www.ncbi.nlm.nih.gov/pmc/articles/PMC3791249/ [10.10.2017]

(2) Maghari BM, Ardekani AM. Genetically Modified Foods and Social Concerns. Avicena Journal of Medical Biotechnology [Internet]. 2011;3(3):109-117. Mund të gjendet: https://www.ncbi.nlm.nih.gov/pmc/articles/PMC3558185/\#CIT0030 [10.10.2017]

(3) Grigore ME, Biscu ER, Alina MH. Approved Genetically Engineered Foods: Types, Properties and Economic Concerns. Genetically Engineered Foods. 2018;85-107

(4) Tsatsakis AM, Nawaz MA, Tutelyan VA, Golokhvast KS, Kalautzi OI, Chung DH et al. Impact on environment, eco system, diversity, and health from culturing and using MGJOs as feed and food. Food Chemical Toxicology. 2017;107:108-121 Mund të gjendet: https://www.ncbi.nlm.nih.gov/pubmed/28645870 [16.10.2017]

(5) Bonny S. Genetically Modified Herbicide - Tolerant Crops, Weeds, and Herbicides: Overview and Impact. Environmental Management. 2016;57(1):31-48 Mund të gjendet:

https://www.ncbi.nlm.nih.gov/pubmed/26296738 [17.10.2017]

(6) Georges F, Ray H. Genome editing of crops: A renewed opportunity for food security. MGJ Crops \& Food. 2017;8(1):1-12 Mund të gjendet: https://www.ncbi.nlm.nih.gov/pubmed/28075688 [29.10.2017]

(7) Okeno JA, Wolt JD, Misra MK, Rodriguez L. Africa's inevitable walk to genetically modified (MGJ) crops: opportunities and challenges for commercialization. New Biotechnology. 2013;30(2):124-30 Dostupno na: https://www.ncbi.nlm.nih.gov/pubmed/22985799 [29.10.2017]

(8) Lachowski S, Jurkiewicz A, Choina P, Florek LM, Buczaj A, Gozdziewska M. Readiness of adolescents to use genetically modified organisms according to their knowledge and emotional attitude towards MGJOs. Annals of Agricultural and Environmental Medicine. 2017;24(2):194200. Mund të gjendet: https://www.ncbi.nlm.nih.gov/pubmed/28664693 [15.10.2017]

(9) Fresco LO. The MGJO stalemate in Europe. Science. 2013;339(6122):883. Mund të gjendet: https://www.ncbi.nlm.nih.gov/pubmed/23430619 [17.10.2017]

(10) Dolezel M, Miklau M, Heissenberger A, Reicheubecher W. Are Limits of Concern a useful concept to improve the environmental risk assessment of MGJ plants? Environmental Sciences Europe. 2017;29(1):7 Mund të gjendet: https://www.ncbi.nlm.nih.gov/pubmed/28261537 [20.10.2017]

(11) Martinelli L, Karbarz M, Siipi H. Science, safety, and trust: the case of transgenic food. Croatian Medical Journal [Internet]. 2013;54(1):91-6. Mund të gjendet: https://www.ncbi.nlm.nih.gov/pubmed/23444254 [1.11.2017. 
(12) Salvio PR, Deyvid NM, Nicolle LFB, Carinne NMC, Claudia RBS. Genetically Engineered Food Crops to Abiotic Stress Tolerance. Genetically Modified Foods. 2018;247279.

(13) Soleyman D, Mohammad R, Sabzalian. Genetically Modified Plants as Sustainable and Economic Sources for RUTFs. Genetically Engineered Foods. 2018;49-84

(14) Patrick JS, Walter CW. Essentials of Healthy Eating: A guide. Journal Midwifery Womens Health [Internet]. 2010;55(6):492-501. Mund të gjendet: https://www.ncbi.nlm.nih.gov/pmc/articles/PMC3471136/ [12.12.2017.]

(15) Kromdijk J, Long SP. One crop breeding cycle from starvation? How engineering crop photosynthesis for rising $\mathrm{CO} 2$ and temperature could be one important route to alleviation. Proceedings Biological Science. 2016;283(1826):20152578. Mund të gjendet: https://www.ncbi.nlm.nih.gov/pubmed/26962136 [1.12.2017.]

16. Aldemita RR, Reano IM, Solis RO; Hautea RA. Trends in global approvals of biotech crops (1992-2014). MGJ Crops \& Food. 2015;6(3):150-66. Mund të gjendet: https://www.ncbi.nlm.nih.gov/pubmed/26039675 [10.11.2017.]

(17) Suzie K, Julian KCM, Pascal MWD. Genetically modified plants and human health. Journal of the Royal Society of Medicine [Internet]. 2008;101(6):290-298. Mund të gjendet: https://www.ncbi.nlm.nih.gov/pmc/articles/PMC2408621/ [10.11.2017.]

(18) Lin CH, Pan TM. Perspectives on genetically modified crops and foof detection. Journal of Food and Drug Analysis [Internet]. 2016;24(1):1-8. Mund të gjendet: https://www.ncbi.nlm.nih.gov/pubmed/28911391 [9.12.2017.]

(19) Zhang R, Guo C, Sui S, Yu T, Wang J, Li N. Comprehensive assessment of milk composition in transgenic cloned cattle. PloS One. 2012;7(11):e49697. Mund të gjendet: https://www.ncbi.nlm.nih.gov/pubmed/23185411 [7.12.2017.]

(20) MGJ Approval Database | MGJO Database | MGJ Crop Approvals - ISAAA.org [Internet]. Isaaa.org.2018. Mund të gjendet: http://www.isaaa.org/MGJapprovaldatabase/default.asp [23.12.2017.]

(21) Bohn T, Aheto DW, Mwangala FS, Fischer K, Bones IL, Simoloka C et al. Pollesnmediated gene flow and seed exchange in small-scale Zambian maize farming, implications for biosafety assessment. Scientific Reports. 2016;6:34483. Mund të gjendet: https://www.ncbi.nlm.nih.gov/pubmed/27694819 [9.12.2017.]

(22) Teoh KT, Requesens DV, Devaiah SP, Johnson D, Huang X, Howard JA et al. Transcriptome analysis of embryo maturation in maize. BMC Plant Biology. 2013;13:19. Mund të gjendet: https://www.ncbi.nlm.nih.gov/pubmed/23379350 [9.12.2017.] 
23. Brookes $\mathrm{G}$, Barfoot $\mathrm{P}$. The global income and production effects of genetically modified (MGJ) crops 1996-2011. MGJ Crops \& Food. 2013;4(1):74-83. Mund të gjendet: https://www.ncbi.nlm.nih.gov/pubmed/23549349 [8.12.2017.]

(24) Arjo G, Capell T, Matias GX, Zhu C, Christon P, Pinol C. Mice fed on a diet enriched with genetically engineered multivitamin corn show no sub-acute toxic effects and no sub-chronic toxicity. Plant Biotechnology Journa [Internet]. 2012;10(9):1026-34. Mund të gjendet: https://www.ncbi.nlm.nih.gov/pubmed/22928600 [9.12.2017.]

(25) Tefera T, Mugo S, Mwimali M, Anani B, Teude R, Beyene Y et al. Resistance of Bt-maize (MON810) against the stem borers Busseola fusca (Fuller) and Chiko partellus (Swinhoe) and its yield performance in Kenya. Crop Protection. 2016;89:202-208. Mund të gjendet: https://www.ncbi.nlm.nih.gov/pubmed/27812235 [9.12.2017.]

(26) Wang X, Komatsu S. Proteomic approaches to uncover bthe flooding and drought stress response mechanisms in soybean. Journal of Proteomics [Internet]. 2018; 172:201-215. Mund të gjendet: https://www.ncbi.nlm.nih.gov/pubmed/29133124 [9.12.2017.]

(27) Fuganti PR, Ferreira LC, Rodrigues Fa, Molinari BHC, Marin SRR, Molinari MDC et al. Characterization of Soybean Genetically Modified for Drought Tolerance in Field Conditions. Frontiers in Plant Science. 2017;8:448

(28) Thao NP, Tran LS. Potentials toward genetic engineering of drought-tolerant soybean. Critical Reviews in Biotechnology. 2012;32 (4):349-62. Mund të gjendet: https://www.ncbi.nlm.nih.gov/pubmed/22181694 [9.12.2017.]

(29) Natarajan S, Lutheria D, Bae H, Lakshman D, Mitra A. Transgenic soybeans and soybean protein analysis: an overview. Journal of Agricultural and Food Chemistry. 2013;61(48):11736 43.

(30) Marinho CD, Martins FJ, Amaral Jr. AT, Goncalves LS, Santos OJ, Alves DP et al. Genetically modified crops: Brazilian law and overview. Genetics and Molecular Research. 2014;13(3):5221-40.

(31) Sapna J, Mukesh KY, Ajay K. Techniques for Production and Quality Assessment of Genetically Modified Foods. Genetically Engineered Foods. 2018;177-202.

(32) Zhou X, Bai X, Xing Y. A Rice Genetic Improvement Boom by Next Generation Sequencing. Current Issues in Molecular Biology. 2017;27:109-126. Mund të gjendet: https://www.ncbi.nlm.nih.gov/pubmed/28885178 [10.12.2017.]

(33) Federico ML, Schmidt MA. Modern breeding and Biotechnological Approaches to Enhance Carotenoid Accumulation in Seeds. Subcellular Biochemistry. 2016;79:345-58.

(34) Vidhyasekaran P, Ponmalar TR, Samiyappan R, Velazhahan R, Vimala R, Ramanathan A et al. Host-Specific Toxin Production by Rhizoctonia solani, the Rice Sheath Blight Pathogen. Phytopathology. 1997;87(12):1258-63. 
(35) Helliwell EE, Yang Y. Molecular strategies to improve rice disease resistance. Methods in Molecular Biology. 2013;956:285-309

(36) Bhullar NK, Gruissem W. Nutritional enhancement of rice for guman health: the contribution of biotechnology. Biotechnology Advances. 2013;31(1):50-7

(37) Alos E, Rodrigo MJ, Zacarias L. Manipulation of Carotenoid Content in Plants to Improve Human Health. Subcellular Biochemistry. 2016;79:311-43

(38) Gayen D, Ghosh S, Paul S, Sarkar SN, Datta SK, Datta K. Metabolic Regulation of Carotenoide-Enriched Golden Rice Line. Frontiers in Plant Science. 2016;7:1622

(39) Moghissi AA, Pei S, Liu Y. Golden rice: scientific, regulatory and public information processes of genetically modified organisms. Critical Reviews in Biotechnology. 2016;36(3):53541.

(40) Wang GP, Yu XD, Sun YW, Jones HD, Xia LQ. Generation of Marker-and/or Backbone-Free Transgenic Wheat Plants via Agrobacterium-Mediated Transformation. Frontiers in Plant Science. 2016;7:1324.

(41) Koning F. Adverse Effects of Wheat Gluten. Annals of Nutrition \& Metabolism. 2015;67(2):8-14.

(42) Giuseppe M. Effector and Suppressor T cells in celiac disease. World Journal of Gastroenterology [Internet]. 2015;21(24): 7349-7356

(43) Ozuna CV, Barro F. Safety evaluation of transgenic low-gliadin wheat in Sprague Dawley rats: An alternative to the gluten free diet with no subchronic adverse effects. Food and Chemical Toxicology. 2017;107(PtA):176-185

(44) Kitta K. Availability and utility of crop composition data. Journal of Agricultural and Food Chemistry [Internet]. 2013;61(35):8304-11

(45) Wilna JR, Jane ME. Safety and Risk Assessment of Food From Genetically Engineered Crops and Animals: The Challenges. Genetically Engineered Foods. 2018;335-368

(46) Kamle S, Ali S. Genetically modified crops: detection strategies and biosafety issues. Gene. 2013;522(2):123-32

(47) Kramkowska M, Grzelak T, Czyzewska K. Benefits and risks associated with genetically modified food products. Annals of Agricultural and Environmental Medicine. 2013;20(3):413-9

(48) Brameld JM, Parr T. Improving efficiency in meat production. The Proceedings of the Nutrition Society. 2016;75(3):242-6

(49) Gerhard F. Influence of Feed From Genetically Modified Plants on the Composition and Quality of Foods of Animal Origin. Genetically Engineered Foods. 2018;109-141 
(50) Braimah JA, Atuoye KN, Vercillo S, Warring C, Luginnah I. Debated agronomy: public discourse and the future of biotechnology policy in Ghana. Global Bioethics. 2017;28(1):3-18

(51) Gruber K. Agrobiodiversity: The living library. Nature. 2017;544(7651):S8-S10

(22) Wang ZY, Brummer EC. Is genetic engineering ever going to take off in forage, turf and bioenergy crop breeding? Annals of Botany. 2012;110(6):1317-25. Mund të gjendet: https://www.ncbi.nlm.nih.gov/pubmed/22378838 [10.11.2017.]

(53) Gilbert N. Case studies: A hard look at MGJ crops. Nature. 2013;497(447):24-6

(54) Lucht JM. Public Acceptance of Plant Biotechnology and MGJ Crops. Viruses. 2015;7(8):4254-81

(55) Jouzami GS, Valijanian E, Sharafi R. Bacillus thuringiensis: a successful insecticide with new environmental features and tidings. Applied Microbiology and Biotechnology. 2017;101(7):26912711

56. sipas tekstit https://www.independentsciencenews.org 57. sipas tekstit https://www.independentsciencenews.org (58) Nicolia A, Manzo A, Veronesi F, Rosellini D. An the overview of the last 10 years of the genetically engineered crop safety research. Critical Reviews in Biotechnology. 2014;34(1):77-88.

(59) Vishal VD, Ashok DC, Vitthall B, Rahul ST, Ashok PG. Genetically Engineered Crops: Opportunities, Constraints, and Food Security at a Glance of Human health, Environmental Impact, and Food Quality. Genetically Engineered Foods. 2018;311-334

(60) Brookes G, Barfoot P. Environmental impacts of genetically modified (MGJ) crop use 19962014: Impacts on pesticide use and carbon emissions. MGJ Crops \& Food. 2016;7(2):84-116

(61) Herman RA, Raybould A. Invoking ideology in the promotion of ecological risk assessment for MGJ crops. Trends in Biotechnology. 2013; 31(4):217-8

(62) Domingo JL. Toxicity studies of genetically modified plants: a review of the published literature. Critical Reviews in Food Science and Nutrition. 2007;47(8):721-33

(63) Fan W, Wang H, Wu Y, Yang N, Yang J, Zhang P. H+-pyrophosphatase IbVP1 promotes efficient iron use in sweet potato [Ipomoea batatas (L.)]. Plant Biotechnology Journal [Internet]. 2017;15(6):698-712

(64) Lonnerdal B. Genetically modified plants for improved trace element nutrition. The Journal of Nutrition [Internet]. 2003;133(5 Suppl 1):1490S-3S

(65) Chen XP, Zhang YQ, Tong YP, Xue YF, Liu DY, Zhang W et al. Harvesting more grain zinc of wheat for human health. Scientific Reports. 2017;7(1):7016 
(66) Alvarez SP, Sida-arrerola JP, Chavez ES, Ardisana EFH. Expression analysis and biochemical characterization of beans plants biofortificated with zinc. Saudi Journal of Biological Science. 2017;24(6):1322-1326

(67) Chattha MU, Hassan MU, Khan I, Chattha MB, Mahmood A, Nawaz M et al. Biofortification of Wheat Cultivars to Combat Zinc Deficiency. Frontiers in Plant Science. 2017;8:281

(68) Lipkie TE, De Moura FF, Zhao ZY, Albertsen MC, Che P, Glassman K et al. Bioaccessibility of carotenoids from transgenic provitamin A biofortified sorghum. Journal of Agricultural and Food Chemistry [Internet]. 2013;61(24):5764-71

(69) Paul JY, Khanna H, Kleidon J, Hoang P, Geijskes J, Daniells J et al. Golden bananas in the field: elevated fruit pro-vitamin A from the Expression of a single banana transgene. Plant Biotechnology Journal [Internet]. 2017;15(4):520-532

(70) Dunn SE, Vicini JL, Glenn KC, Fleischer DM, Greenhawt MJ. The allergenicity of genetically modified foods from genetically engineered crops: A narrative and systematic review. Annals of Allergy, Asthma \& Immunology. 2017;119(3):214-222-3

(71) Panda R, Ariyarathna H, Amnuaaycheewa P, Tetteh A, Pramod SN, Taylor SL et al. Challenges in testing genetically modified crops for potential increases in endogenous allergen expression for safety. Allergy. 2013;68(2):142-51

(72) De Francesco L. How safe does transgenic food need to be? Nature Biotechnology. 2013;31(9):794-802

(73) Goodman RE, Panda R, Ariyarathna H. Evaluation of endogenous allergens for the safety evaluation of genetically engineered food crops: review of potential risks, test methods, examples and relevance. Journal of Agricultural and Food Chemistry. 2013;61(35):8317-32

(74) Adel-Patient K, Wal JM. [Animal models for assessment of MGJO allergenicity: advantages and limitations]. European Annals of Allergy and Clinical Immunology. 2004;36(3):88-91

(75) Schwartz SA. The great experiment: genetically modified organisms, scientific integrity, and national wellness. Explore (NY). 2013;9(1):12-6

(76) Farmer DR, Edrington TC, Kessenich CR, Wang C, Petrick JS. Improving insect control protein activity for MGJ crops: A case study demonstrating that increased target insect potency can be achieved without impacting mammalian safety. Regulatory Toxicology and Pharmacology. 2017;89:155-164

(77) Hammond B, Kough J, Heronet GC, Jez JM. Toxicological evaluation of proteins introduced into food crops. Critical Review in Toxicology. 2013;43 Suppl 2:25-42

(78) Yau YY, Stewart CN Jr. Less is more: strategies to remove marker genes from transgenic plants. BMC Biotechnology. 2013;13:36. 
(79) Gostin LO. Genetically Modified Food Labeling: A "Right to Know"? JAMA. 2016;316(22):2345-2346

(80) Ligji për ushqime të modifikuara gjenetike RKS

\section{SHTPJCAT}

